$$
\text { RFP- } 5045
$$

\title{
GEOLOGIC AND GEOTECHNICAL ASSESSMENT RFETS BUILDING 371, ROCKY FLATS, COLORADO (U)
}

WSRC-TR-95-0482

Revision 0

December 13, 1995
Reviewed by: L. A. Salomone SRS Chief Geotechnical Engineer

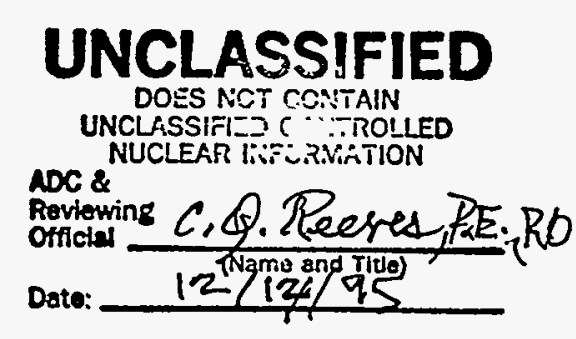

Westinghouse Savannah River Company Engineering \& Construction Services Division Site Geotechnical Services Department 


\section{DISCLAIMER}

This report was prepared as an account of work sponsored by an agency of the United States Government. Neither the United States Government nor any agency thereof, nor any of their employees, make any warranty, express or implied, or assumes any legal liability or responsibility for the accuracy, completeness, or usefulness of any information, apparatus, product, or process disclosed, or represents that its use would not infringe privately owned rights. Reference herein to any specific commercial product, process, or service by tradename, trademark, manufacturer, or otherwise does not necessarily constitute or imply its endorsement, recommendation, or favoring by the United States Government or any agency thereof. The views and opinions of authors expressed herein do not necessarily state or reflect those of the United States Government or any agency thereof. 
WESTINGHOUSE SAVA NNAH RIVER COMPANY

E\&CS SITE GEOTECHNICAL SERVICES DEPARTMENT

GEOLOGIC AND GEOT'RCHNICAL ASSESSMENT

RFETS BUILDING 371, ROCKY FLATS, COLORADO
WSRC-TR-95-0482

REVISION 0

December 13, 1995

Page 3

\section{TABLE OF CONTENTS}

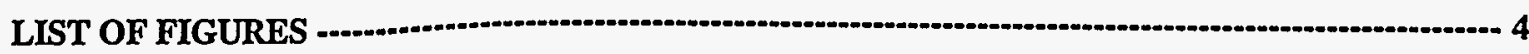

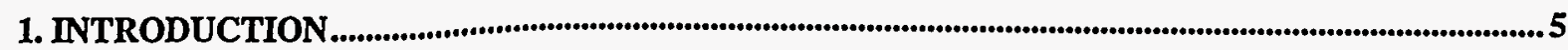

2. PURPOSE AND OBJECTIVES

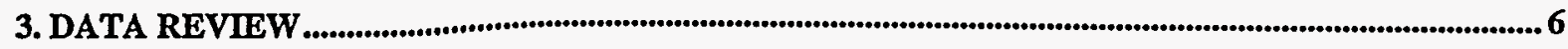

4. GEOLOGY AND STRATIGRAPHY

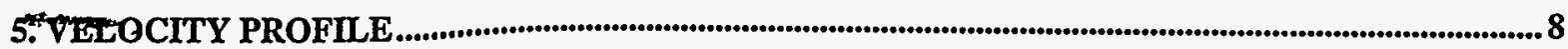

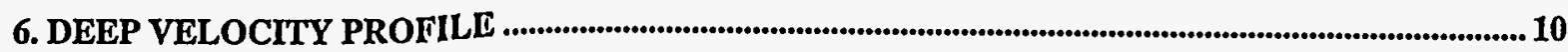

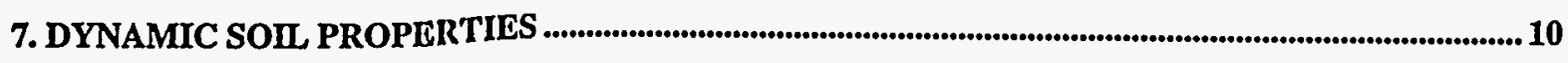

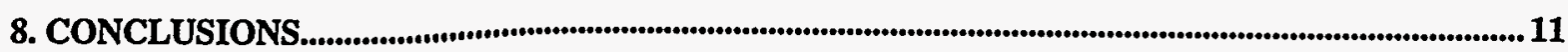

9. RECOMMENDATIONS

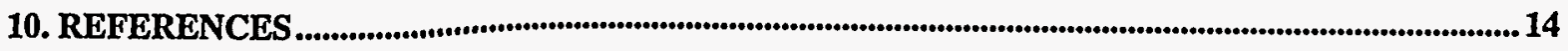

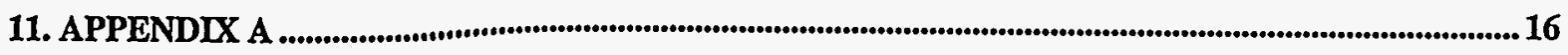

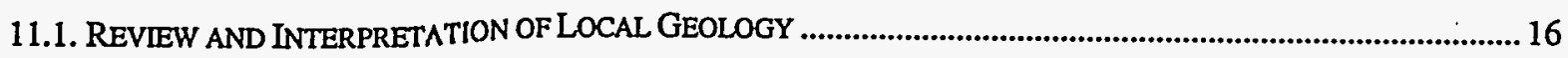

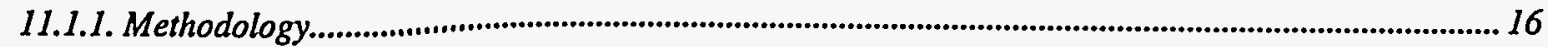

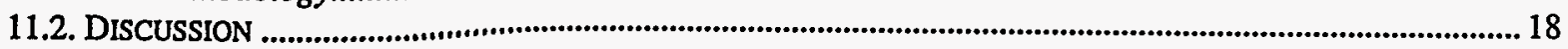

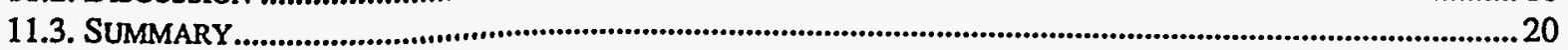

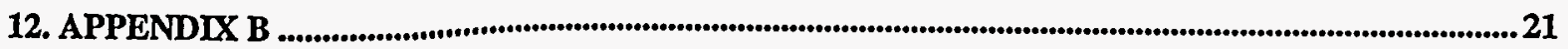

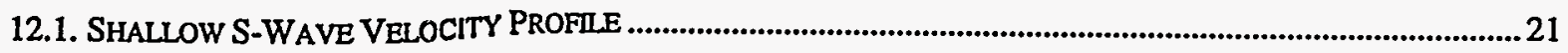

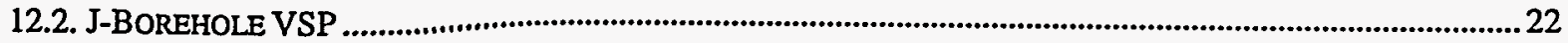

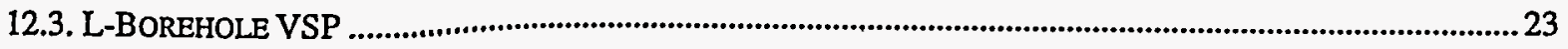

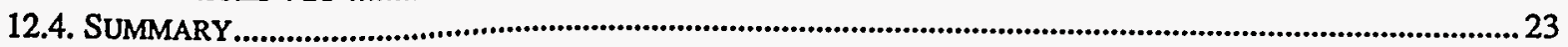




\section{List of Figures}

Figure Description $\quad$ Page

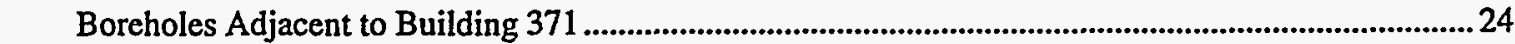

Depth Limits of Investigation Adjacent to Building 371 ..........................................................................25

Shallow Stratigraphy Under Building 371 ...............................................................................................26

WSRC Hole-J Interval Velocity Plot ......................................................................................................... 27

WSRC Hole-L Interval Velocity Plot ....................................................................................................... 28

Blackhawk Hole-J Shear Wave Travel Time Curves............................................................................29

Blackhawk Hole-L Shear Wave Travel Time Curves ...................................................................................... 30

Blackhawk Hole-J Ascending P- \& S-Wave Data Versus Averaged P-Wave Curve................................ 31

G/Gmax Curves Used by RFETS (1994) after EPRI (1993) ..................................................................... 32

Damping Curves Used by RFETS (1994) after EPRI (1993) ...................................................................... 33

Recommended Range of G/Gmax for Claystone and Alluvial Gravels....................................................... 34

Recommended Range of Damping for Claystone and Alluvial Gravels ....................................................35

Building 371 Foundation Borehole Top of "Very Hard Clay" ................................................................... 36

Building 371 Caisson Data Top of "Very Hard Bedrock".......................................................................... 37

Building 371 Caisson Data Top of "Medium Hard Bedrock" .................................................................. 38

Stratigraphic \& Structure Correlation Panel ..........................................................................................39

Averaged P-Wave Velocity Curve for Borings 44092, 43992, 44192 ................................................... 40

Blackhawk Hole-J Descending P- \& S-Wave Data Versus Averaged P-Wave Curve .............................. 41

Blackhawk Hole-J Ascending and Descending P- \& S-Wave Data ............................................................ 42

Hole-J "Ascending" Raw Recorded Motions vs Depth.................................................................................. 43

Hole-L “Ascending” Raw Recorded Motions vs Depth ................................................................................. 44 


\section{Introduction}

This report describes the review and evaluation of the geological, geotechnical and geophysical data supporting the design basis analysis for the Rocky Flats Environmental Test Site (RFETS) Building 371. The primary purpose of the geologic and geotechnical reviews and assessments described herein are to assess the adequacy of the crustal and near surface rock and soil model used in the seismic analysis of Building 371.

It is well documented that the near surface site characteristics (layer velocity and density contrasts, layer orientation, material absorption, and higher-strain dynamic properties) can have an effect on seismic motions as compared to total ray-path effects as a whole (e.g., EPRI, 1993). Consequently, the basis for the site response model for a nuclear facility must be fully documented and verifiable. The Building 371 ground motion assessments apply the shallow velocity and density profile described in RFETS (1994). The predicted site response is particularly sensitive to the depth and the degree of contrasting velocities, particularly the depth at which the shear wave velocity increases to 2,000 feet per second (fps).

This report is organized in six sections and two appendices, including: 1) Data Review 2) Review and Interpretation of Local Geology 3) Shallow S-wave Velocity Profile 4) Deep S-wave Velocity Profile 5) Dynamic Soil Properties, 6) Recommendations, Appendix A, Review and Interpretation of Local Geology and Appendix B Shallow Shear Wave Velocity Interpretation.

\section{Purpose and Objectives}

This review was requested by the RFETS Seismic Evaluation Program. The purpose was to determine the adequacy of data to support the design basis for Building 371, with respect to seismic loading. The objectives required to meet this goal were to: 1) review techniques used to gather data 2) review analysis and interpretations of the data; and 3) make recommendations to gather additional data if required. Where there were questions or inadequacies in data or interpretation, recommendations were made for new data that will support the design basis analysis and operation of Building 371. In addition, recommendations are provided for a geologic and geophysical assessment for a new facility at the Rocky Flats Site. 
WESTINGHOUSE SAVANNAH RIVER COMPANY E\&CS SITE GEOTECHNICAL SERVICES DEPARTMENT GEOLOGIC AND GEOTECHNICAL ASSESSMENT RFETS BUILDING 371, ROCKY FLATS, COLORADO
WSRC-TR-95-0482

REVISION 0

December 13, 1995

Page 6

\section{Data Review}

The subsurface conditions underlying Building 371 and adjacent areas were evaluated using several RFETS sources. These sources were reviewed to provide data to support the objectives previously outlined. In addition, two principal goals were: 1 ) verify stratigraphy generated from RFETS scientists with seismic velocities (the development of a seismic stratigraphy), and 2) review existing geological data for structural and/or three dimensional conditions within the area of interest. Geologic data contained in the following references were reviewed:

- Well Abandonment and Replacement Program Final Report, Nov. 1993, -21.7-EXD-0761, EG\&G Rocky Flats

- Final Report, Evaluation of the Capability of Inferred Faults in the Vicinity of Building 371 Rocky Flats Environmental Technology Site, Colorado, Feb. 1995, GeoMatrix Consultants

- Seismic and Geological Investigation and Design Criteria for Rocky Flats Plutonium Recovery and Waste Treatment Facility, Sept. 1972, Rev. June, 1979, JABE-CFB-01, John A. Blume and Assoc.

- Final Report, Deterministic Ground Motion Assessment for Building 371, Rocky Flats Environmental Technology Site, Colorado, July, 1995, Geomatrix Consultants

- Shear Wave Velocity Investigation, Rocky Flats Plant, Golden, Co., Blackhawk-CEES, Nov. 1993

- Shear Wave Velocity Investigation, Rocky Flats Plant, Golden, Co., Blackhawk-CEES, Mar. 1994

- Phase II Geologic Characterization Data Acquisition, March 1992, Ebasco Services, Inc.

- Seismic Hazard Study for Rocky Flats Plant, Systematic Evaluation Program, Sept. 1994, Risk Engineering, Inc.

- Plutonium Recovery Facilities, The A.E.C. Rocky Flats Plant, Oct. 1972, WoodwardClevenger \& Associates, Inc.

- Geologic Characterization Report for the Rocky Flats Environmental Technology Site, March 1995, EG\&G Rocky Flats 
In addition, the following drawings and photographs were used to provide data for reconstructing bedrock maps underlying the facility and to provide a visual understanding of the near surface geology beneath the building:

- Reference Drawings 25154-001 through 009, Plutonium Recovery Facility Cast in Place Piles Plan (for foundation borings and caisson data)

- Historical Excavation Pictures for Building 371, including: 9217-EXD-024, 025, 027; $15341-37 ; 18360-10 ; 14451-17$; 22078-01; 22003-06; 11185-02; 42435-00; 17393-05, $08 ; 17524-02,04 ; 17657-04,05,06,11 ; 17757-01 ; 18316-02,09 ; 18360-05,06,07,08$, $09,10,11 ; 18376-03 ; 22003-06 ; 22078-01$

Unpublished subsurface information was also used to review and derive local geological conditions. These data included:

- Geophysical Logs (in electronic and analogue format) from coreholes adjacent to and near Building 371

- Core description logs from boreholes adjacent to and near Building 371

All of the data and reports were provided by RFETS scientists. Geological information was reviewed and plotted on ARC-INFO base maps provided by RFETS and cross-sections were generated on Terrasciences ${ }^{\circledR}$ TerraStation software and transferred into INTERGRAPH® format for display.

The scope of geologic and geotechnical information for siting a facility, such as Building 371 , requires a combination of subsurface information at the specific location for that facility. The subsurface information for analysis are categorized as direct and indirect below:

- Direct Methods

- soil and /or rock borings

- cone penetrometer

- test pits or trenching

- sampling and laboratory testing

- Indirect Methods

- seismic refraction and reflection

- downhole geophysics 
WESTINGHOUSE SAVANNAH RIVER COMPANY

E\&CS SITE GEOTECHNICAL SERVICES DEPARTMENT

GEOLOGIC AND GEOTECHNICAL ASSESSMENT

RFETS BUILDING 371, ROCKY FLATS, COLORADO
WSRC-TR-95-0482

REVISION 0

December 13, 1995

Page 8

For Building 371, the information available was generally indirect or data that was not specific to the location of interest. In addition, the original investigation had no site specific dynamic properties for the underlying materials, which is needed for a thorough seismic qualification.

An investigation for a new facility would combine direct as well as indirect methods to determine the stratigraphy and engineering properties for design.

As part of this assessment, a large data set was reviewed in an attempt to meet the purpose of the review as outlined in section 3.0. In the final analysis, we determined the data does not support the current shallow model and additional data will be required to validate a model for ongineering analysis.

\section{Geology and Stratigraphy}

The initial review of RFETS required a basic understanding of the geology and the site location. This was accomplished through interviews with RFETS personnel and study of selected reports. The site and boring locations are given on Figure 1. The general geology of RFETS is shown in Figure 2 along with the depth of investigations and the number of associated borings. The geology is broken into a few distinct formations: alluvium, Laramie Formation, Fox Hills Sandstone and Pierre Shale.

The local stratigraphy beneath Building 371 was constructed using information from original borings, geophysical logs and available laboratory test results. The local stratigraphy is shown as a section on Figure 3 and is heavily dependent upon environmental borings 43992 , 44092 , and 44192 located on Figure 1 . With the available data it is very difficult to determine the stratigraphy beneath the building due to dipping formations and potential faulting features, as described in Appendix A.

The general formation layering was identified utilizing limited direct information and was poorly constrained by the indirect geophysical methods. This enabled the top of the weathered and unweathered claystone to be generally identified. However, it was not possible to correlate the velocity profile to the stratigraphic profile. The data from Blackhawk had limited points verified and in general had wide variability and inconsistencies, as will be described in the next section.

\section{Velocity Profile}

The objective of the velocity profile evaluation was to validate the deep and shallow shear wave velocities as presented in the design criteria. For discussion purposes, the bedrock 
outcrop is defined as that material which has shear wave velocities of about $2000 \mathrm{fps}$ or greater. The average shallow ( $<500 \mathrm{ft}$ ) shear-wave velocity profile for Building 371 was inferred from Vertical Seismic Profile (VSP) investigations conducted for EG\&G by Coleman Energy \& Environmental Systems - Blackhawk Geosciences Division (CEES-BGD) $(1993,1994)$. A total of eight boreholes were logged in the general vicinity of Building 371 (Figure 1); boreholes B, C, D, E, F, G and J were logged in the first investigation conducted from July through August, 1993; hole L was completed in February, 1994. The VSP's were conducted with the objective of determining seismic compression and shear wave velocities as a function of depth in each hole. The location of logged holes ranged from 300 feet to greater than 1500 feet from the mapped location of the building foundation.

Boreholes $C, D, F$, and $G$ were too shallow for site response evaluation purposes. Holes $B$, $\mathrm{E}$, and $\mathrm{J}$ were interpreted to a depth range of approximately 110 feet - 140 feet. Hole $L$ was interpreted to a depth of nearly 500 feet. The deeper profile interpretations (to depths of approximately 130 feet) appear to be reasonably consistent from hole-to-hole. However, there are instances where the interpreted S-wave speeds exceed the P-wave speeds without explanation or cause (Hole D). Based on availability of field data and depth extent of measurements, holes $\mathrm{L}$ and $\mathrm{J}$ were chosen for re-analysis.

Holes $\mathrm{L}$ and $\mathrm{J}$ were independently reviewed as discussed in Appendix B. The S-wave arrival times, when discernible, were picked and then plotted versus depth as seen on Figures 4 and 5. The number of travel-time "picks" are less than the number established by Blackhawk as can be seen in Figures 6 and 7. Also the interval velocities vary from Blackhawk velocities by 10 to $50 \%$ (see Figures $4 \& 5$ ). An additional observation can be made from Figure 8 in which the $S$-wave and $P$-wave are plotted against the averaged $P$-wave. The development of the average $\mathrm{P}$-wave curve is presented in Appendix A. The data is inconsistent from set to set and a trend for Poisson ratio cannot be established.

Because of difficulty in finding the S-wave arrival in many portions of the L-borehole record, only fifteen S-wave picks could be made in the $40-500 \mathrm{ft}$ depth interval. No S-wave arrivals could be picked with high degree of confidence in the depth range of about $80-180 \mathrm{ft}$. If the $180-240 \mathrm{ft}$ travel-time picks are valid, then 2,000 fps speeds are expected between depths of about $80 \mathrm{ft}$ and $180 \mathrm{ft}$. This depth is critical to the site response and should be resolved. In summary, the techniques used to collect and process the original VSP data were industry standard. Independent analysis of data collected in borehole $\mathrm{L}$ indicate that $\mathrm{S}$-waves could not be unambiguously selected at many sensor depths, resulting in a relatively small number of Swave picks, particularly for deeper portions of the section. The inability to identify S-waves could be caused by: 1) high rates of energy loss (damping) of the direct shear-wave 2) scattering of signal 3) high background noise levels 4) stimulation of interfering borehole tube wave or 5) a combination of the above causes. The depth and magnitude of the 
WESTINGHOUSE SAVANNAH RIVER COMPANY

E\&CS SITE GEOTECHNICAL SERVICES DEPARTMENT

GEOLOGIC AND GEOTECHNICAL ASSESSMENT

RFETS BUILDING 371, ROCKY FLATS, COLORADO
WSRC-TR-95-0482

REVISION 0

December 13, 1995

Page 10

significant velocity contrasts reported by Blackhawk could not be independently verified. However, where velocity intervals could be estimated with confidence, average velocities were within about $10-50 \%$ of values reported by Blackhawk, see Figures 4 and 5.

\section{Deep Velocity Profile}

The velocity profile used in the soil amplification studies for Building 371 (Risk Engineering, 1994) was derived by averaging the Blackhawk S-wave velocity profiles (all less than $500 \mathrm{ft}$ in depth). Site response statistics were estimated by using a one-dimensional "soil" and "rock" model derived from the Blackhawk models and by randomizing material properties in the soil column. Rock outcrop motions were specified at the 2,000 fps velocity, corresponding to a depth of $100 \mathrm{ft}$ in the median velocity model. This model was extended in depth (50 km) by using two available P-wave models: (1) a $4 \mathrm{~km}$-deep sonic velocity log measured at the Rocky Mountain Arsenal; and (2) the results of a deep seismic refraction survey. The S-wave velocities for the deep model were derived assuming a Poisson relation. Analysis of the effects of a dipping interface in the upper crust were also considered. The two-dimensional model was based on a seismic reflection survey (Ebasco, 1992). Parametric ground motion studies conducted for the deep profile indicate that uncertainty associated with the deep velocity structure will not significantly impact the design basis ground motions for frequencies greater than $1 \mathrm{~Hz}$ (discussions at Rocky Flats meeting held November 15, 1995 with W. Silva). Therefore, the assumed deep velocity profile does not require further validation. It was determined, however, that the shallow velocity profile would be most influential to the site response.

\section{Dynamic Soil Properties}

The soil type, plasticity index, and depth of the soils are important factors affecting the characteristics of the shear modulus reduction and damping curves. Very limited geotechnical data exists to describe the material properties of the surficial gravels and underlying claystone at Building 371. The original foundation report for the facility (Woodward-Clevenger, 1972) documents only a handful of Atterberg limit tests and grainsize analyses for the soil profile. For example, only one Atterberg limit test was performed in the claystone. Hence, this report is of little value for assessing the types of materials encountered and thus, the possible range of dynamic behavior of the materials.

Also, no site-specific shear modulus reduction and damping curves have been developed for Building 371. Thus, the preliminary dynamic response analyses outlined in the systematic evaluation program (RFETS, 1993) used generic curves from the Electric Power Research Institute (EPRI, 1993) for both the alluvium and claystone materials. The applied curves are shown in Figures 9 and 10. These curves are applicable for generic site response studies in 
WESTINGHOUSE SAVANNAH RIVER COMPANY

E\&CS SITE GEOTECHNICAL SERVICES DEPARTMENT

GEOLOGIC AND GEOTECHNICAL ASSESSMENT

RFETS BUILDING 371, ROCKY FLATS, COLORADO
WSRC-TR-95-0482

REVISION 0

December 13, 1995

Page 11

Eastern North America and to soils in the range of gravelly sands to low plasticity silty or sandy clays. They should not be applied to either very gravelly or very clayey deposits. (EPRI, 1993). Because RFETS is not an eastern U.S. site and the surficial alluvial soils are predominately graveis underlain by clayey soils (i.e., claystone), the applied generic curves do not appear to be appropriate for this site and would underestimate the stiffness of the claystone at higher strain values and potentially overestimate that of alluvium.

Until site-specific curves are developed for Building 371, bounding analyses should be completed using a range of strain-dependent properties. Figures 11 and 12 give possible ranges which may be appropriate for future preliminary analyses. These plotted ranges are based on generic curves published in the geotechnical literature for gravelly and clayey soils.

\section{Conclusions}

The use of indirect methods of investigation such as geophysical data must be linked with direct data and should not be used as the primary method of investigation. This is what was done in the Blackhawk investigation. It is important to define the shallow velocity and dynamic property profile, as they have the potential to shift the soil column frequency and amplify or deamplify motions. It is important from both a safety and a cost effectiveness basis that the stratigraphy and properties at the site be adequately defined. As a result of this review the following conclusions are made:

- The available data does not support the current shallow model. Additional data will be required to validate a model for engineering analysis.

- The horizons associated with alluvium and claystone horizons were roughly established.

- The Blackhawk shear-wave velocity profile could not be independently verified. The data were reprocessed and independently reviewed. The Blackhawk picks were not consistently reproducible. The picks that could be made did not result in sufficient depth resolution for engineering purposes. Because the Blackhawk data were not verified, the interval velocities could not be related to stratigraphy.

- The dynamic properties used in the analysis could not be justified for the claystone material. The properties used for the alluvium, although they may not be appropriate, were conservative. 


\section{Recommendations}

The above conclusions were discussed at a meeting in Denver, Colorado on November 15, 1995 with C. Costantino, W. Silva, C. Miller, F. Grigsby, W. Peregoy, R. Youngs and F. Loceff. As a result of those discussions a balanced approach was recommended with respect to further geologic and geotechnical work for Building 371. Those recommendations are us follows:

- One hole should be drilled to a depth of 500 feet to further establish the profile at Building 371 for analysis and site response. The following should be performed in the completed hole:

Geophysical Logs

- Down Hole Velocity Logs

- Oyo Velocity Log

- Sample Claystone at 10 foot intervals to 200 feet, then every 50 feet to the bottom of the hole (pull and describe drill cuttings at 5 foot depth intervals to total depth of hole)

- Sample the alluvium for index and classification testing

- Complete a series (10 - 20) of seismic piezocone penetration test soundings SCPT's to dofine the shallow stratigraphy, and obtain shear-wave velocity.

- Perform laboratory testing on the claystone samples to verify dynamic properties of the material. This testing should be done at multiple frequencies and confining pressures. Detailed geotechnical sampling and testing should be done to determine the appropriate material properties (e.g., index and classification tests) of each major stratum. This should be done in conjunction with an "undisturbed" sampling program.

- Shallow insitu density tests should be performed in the fill adjacent to Building 371 .

- All boring locations shall be coordinated with Rocky Flats personnel.

- Sensitivity studies for the possible effects of shallow dipping bedrock layers and surface topography on ground motion should be conducted. The sensitivity studies should resolve questions associated with the dip of the " $A$ " Claystone layer.

A gencral recommendation was made by the group attending the meeting on November 15 , 1995 concerning the subcontracting of these tasks. Where specialized work is involved, the specifications should be very detailed, and the bid list should be restricted to qualified 
contractors only. Evaluation of the bidders should be based on technical merits. In some cases a sole source justification may be required.

In addition, at the meeting, we were asked to provide geotechnical recommendations for a new facility. For this recommendation, we are assuming a similar structure at a "grass roots" location, with no existing subsurface information in the immediate area. Following is the recommended program (subject to change based on available data and actual subsurface conditions):

- 1 deep hole ( 500 feet \pm ) logged similar to the deep hole for Building 371

- 12 SCPTs (150 foot deep or refusal)

-8 Borings - 2@ 150 feet, 6 @ 75 feet (through the weathered claystone)

- lab testing (assume $\$ 100,000$ )

- 1 cross-hole seismic survey

- 1 reflection survey

- data analysis and reporting 
WESTINGHOUSE SAVANNAH RIVER COMPANY

E\&CS SITE GEOTECHNICAL SERVICES DEPARTMENT

GEOLOGIC AND GEOTECHNICAL ASSESSMENT

RFETS BUILDING 371, ROCKY FLATS, COLORADO
WSRC-TR-95-0482

REVISION 0

December 13, 1995

Page 14

\section{REFERENCES}

EPRI, 1993, Electric Power Research Institute, "Guidelines for Determining Design Basis Ground Motions," Volume 2: Appendices for Ground Motion Estimation, EPRI TR-102293, Project 3302, Final Report, November 1993

Final Report, Deterministic Ground Motion Assessment for Building 371, Rocky Flats Environmental Technology Site, Colorado, July, 1995, Geomatrix Consultants, Shear Wave Velocity Investigation, Rocky Flats Plant, Golden, Co., Blackhawk-CEES, Nov. 1993

Final Report, Evaluation of the Capability of Inferred Faults in the Vicinity of Building 371 Rocky Flats Environmental Technology Site, Colorado, Feb. 1995, GeoMatrix Consultants

Geologic Characterization Report for the Rocky Flats Environmental Technology Site, March 1995, EG\&G Rocky Flats

Historical Excavation Pictures for Building 371 including: 9217-EXD-024, 025, 027; 1534137 ; 18360-10; 14451-17; 22078-01; 22003-06; 11185-02; 42435-00;17393-05, 08; 17524-02, $04 ; 17657-04,05,06,11 ; 17757-01 ; 18316-02,09 ; 18360-05,06,07,08,09,10,11 ; 18376-$ $03 ; 22003-06 ; 22078-01$

Phase II Geologic Characterization Data Acquisition, March 1992, Ebasco Services Inc. Seismic Hazard Study for Rocky Flats Plant, Systematic Evaluation Program, Sept. 1994, Risk Engineering, Inc.

Plutonium Recovery Facilities, The A.E.C. Rocky Flats Plant, Oct. 1972, WoodwardClevenger \& Associates, Inc.

Reference Drawing 25154-001 through 009, Plutonium Recovery Facility Cast in Place Piles Plan

RFETS, 1994, Rocky Flats Environmental Technology Site, "Building 371 Structural Analysis Criteria Outline," Systematic Evaluation Program, Revision 2, January, 13, 1994

Risk Engineering, Inc., 1994, Seismic Hazard Analysis for the Rocky Flats Plat: Report prepared for EG\&G Rocky Flats, Inc. Report Number 9217-COO-204, Rev. 0, September 29, Appendix F Soil Amplification Studies 
WESTINGHOUSE SAVANNAH RIVER COMPANY

E\&CS SITE GEOTECHNICAL SERVICES DEPARTMENT

GEOLOGIC AND GEOTECHNICAL ASSESSMENT

RFETS BUILDING 371, ROCKY FLATS, COLORADO
WSRC-TR-95-0482

REVISION 0

December 13, 1995

Page 15

Rollins, K. M., Barfuss, D. L., and Daily W., in press, "Shear Modulus and Damping

Relationships for Gravels," Journal of Geotechnical Engineering, ASCE

Seed, H. B., Wong, R. T., Idriss, I. M., and Tokimatsu, K., "Moduli and Damping Factors for Dynamic Analyses of Cohesionless Soils," Earthquake Engineering Research Center, Report No. UCB/EERC-84/14, September 1984, College of Engineering, University of California at Berkeley

Seismic and Geological Investigation and Design Criteria for Rocky Flats Plutonium Recovery and Waste Treatment Facility, Sept. 1972, Rev. June, 1979, JABE-CFB-01, John A. Blume and Assoc.

.

Vucetic, M., Dobry, R., 1991, "Effects of Soil Plasticity on Cyclic Response," Journal of Geotechnical Engineering, ASCE, Vol. 117, No. 1, 1991, pp. 89-107

Well Abandonment and Replacement Program (WARP) Final Report, Nov. 1993, 9217-EXD-0761, EG\&G Rocky Flats 
WESTINGHOUSE SAVANNAH RIVER COMPANY

E\&CS SITE GEOTECHNICAL SERVICES DEPARTMENT

GEOLOGIC AND GEOTECHNICAL ASSESSMENT

RFETS BUILDING 371, ROCKY FLATS, COLORADO
WSRC-TR-95-0482

REVISION 0

December 13, 1995

Page 16

\section{Appendix A}

\subsection{Review and Interpretation of Local Geology}

\subsubsection{Methodology}

Evaluation of the shallow geology underlying Building 371, as based on borehole geophysical data and lithologic core descriptions, used the following approach.

Fourteen borehole geophysical logs (from boreholes 44092, 43992, 44192, 43892, 42592, $4262,43292,43792,42892,693,993,1193,1293,1493)$ provided in paper and electronic format were loaded into the Terrastation. Logs that were not in electronic format were digitally scanned into an ASCI format and also loaded into the Terrastation. Each individual log was plotted at the same scale for initial correlation. Plots included gamma curve, acoustic velocity ( $\mathrm{P}$-wave from delta- $\mathrm{t}$ ) and neutron curve. Data from eleven of the borings with geophysical logs had core descriptions (from Fred Grigsby, personnel communication and WARP, 93) which were compared to log curve signatures. A common datum point (5900 feet above mean sea level) was used for structural and stratigraphic correlation alignment on each plotted log.

During geophysical log data entry, lithologic data from foundation boreholes and caisson boring descriptions (RFETS Reference Drawing 25154) were digitized and mapped to evaluate the shallow geology immediately underlying the building. The term "very hard clay" is from boring descriptions in Woodward-Clevenger (1972). The terms "very hard bedrock" and "medium hard bedrock" are from Reference Drawing 25154. Figure 13 shows the general structure of the "very hard clay", presumed to be the non-weathered Laramie, since the depths are approximately the same as those from surrounding boreholes. Figure 14 contours elevations taken from the caisson boring logs described as the "very hard bedrock", assumed to be the "very hard clay" of the foundation borings. Figure 15 was generated using the caisson boring data described as top of "medium hard bedrock". The Figure 15 data is highly variable, less defined and is not used for further discussion.

A correlation panel (not cross-section), Figure 16, was generated using representatives of the geophysical logs as described above. This panel included borings 1293, 44092, 43992, 44192,43792 and 1493 as referenced in Figure 1. These logs were chosen to provide examples from along geologic strike (borings 1493 and 43792) compared with the borings immediately adjacent to Building 371 (borings 44192, 43992, 44092 and 1293). Borings 1293 and 1493 were also chosen because they were associated with the Blackhawk shear wave study. Additional logs $(42592,42692,43292,42892$ and 43892) were reviewed but not used in this correlation panel. Maintaining the 5900 foot horizontal datum allows for a 
correlation to be made between borings as a suggestion of structural and stratigraphic relationships within the area of Building 371.

Core log descriptions for many of the borings (from WARP, 1993 and Fred Grigsby, personal communication) included sieve analyses performed to classify the sediments at various depths within the upper Laramie Formation. These sieve analyses were compared to their corresponding lithology description and to the corresponding gamma curve values. A gamma curve range of values was created to correlate with silty.claystone, claystone with greater than 90 percent clay, and sandy siltstone with greater than 25 percent very fine grained sand. The gamma log curve was color coded to correspond to the appropriate lithology. No consistent correlations were apparent between lithology and the neutron or acoustic velocity curves except that the "A-Claystone" as defined by RFETS geologists, generally could be defined by an increased gamma count interval and a corresponding decreased neutron count interval. The characteristic nature of the sediments and base of the alluvium has been consistently determined by field sample evaluation.

Once the geological correlation was established, an attempt was made to compare compressional and shear wave velocities from the CEES-Blackhawk data (hereafter referred to as the Blackhawk Report) to acoustic compressional wave values (delta-t) from the geophysical logs for the nearby boreholes. Acoustic data from borings 44192, 44092 and 43992 (the delta-t data for boring 43892 were not available) were adjusted for surface elevation and averaged to form a composite P-wave acoustic velocity curve for the shallow geology underlying Building 371. This averaged comparison curve is shown on Figure 17. Averaged and approximate tops of weathered, and non-weathered zones of the Laramie Formation, as approximated from notations on the core descriptions, are shown on the curve, as is the approximate " $A$ " claystone horizon.

Using the averaged curve as a standard, Blackhawk Hole J (boring 1293) ascending and descending P- and S-wave values, determined from the Blackhawk report, are plotted for a comparison. Hole $\mathrm{J}$ was chosen because it is nearest to Building 371 and is representative of the other Blackhawk shear wave test borings. Figure 8 compares ascending data to the composite average curve and Figure 18 compares descending P-wave velocities. The corresponding shear wave velocities from the Blackhawk tables are also plotted on the graphs for comparison. Figure 19 combines the ascending and descending . 


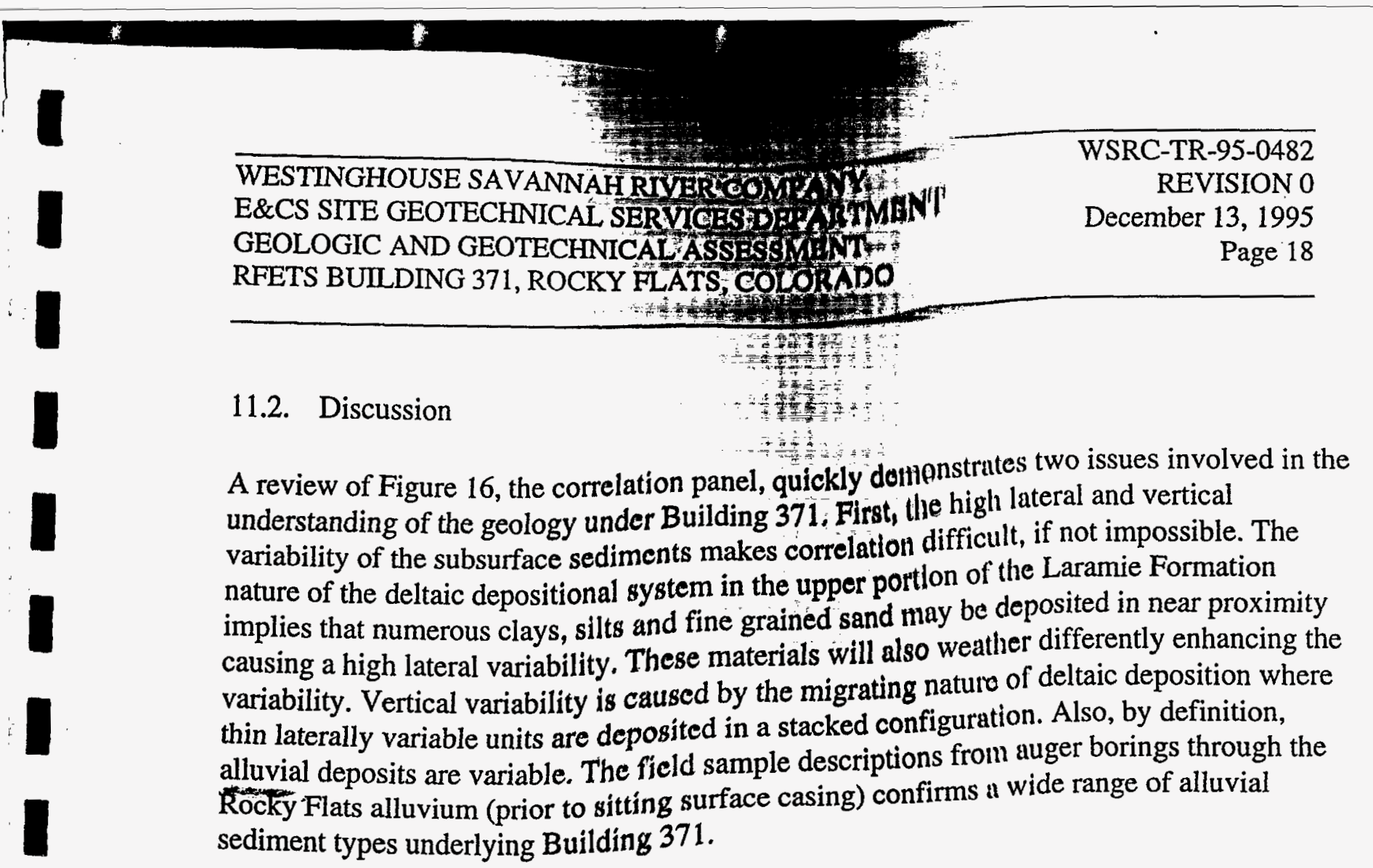

Secondly, because of the lithology variability, correlation of more than the interpreted " $A$ " claystone (derived from core descriptions and interpolated across the panel). is not possible using shallow borings and the determination of three dimensional geologic structure or the modeling of geological features is precluded. The lithology of the Laramie Formation is consistently variable (there are no definitive marker horizons), therefore log correlations and mapping is based on a best-guess approach. In order to determine the geometry of the Laramie, i. e., the dip of the beds, it is necessary to define a defonsible marker horizon, which probably is the Fox Hills Sandstone Formation or the Pierre Shulo. It is possible to use shallow data from some of the borings to verify existing interpretations. The change in the elevation of the "A" claystone is consistent along strike (from borings 1493 to 43792) and then changes abruptly from boring 43792 to boring 44192 , suggesting the presence of fault \#2. The change in the elevation of the " $A$ " claystone from boring 44192 to boring 43992 may be caused by a change in dip or by the near presence of inferred fault $2 a$ as described in the Geological Characterization Report, dated March, 1995.

Figure 3 shows the probable impact of the regional dip on the varying thicknesses of the alluvium (although local effects cannot be precluded) but also shows the structural offset character of the "A" claystone (borings 43992 and 44192 are "up' by 30 feet relative to borings 43892 and 44092). Based on regional dip considerations, the presence of faulting throughout the RFETS, the presence of numerous fractures and slickensides in the core descriptions, and the regional geological setting of the RFETS, the large vertical offset between borings 43792 and 44192 strongly suggest that inferrod Fault \#2 (from the March 1995 Geological Characterization Report) exists. Trenching studies through the Rock Flats alluvium north of Building 371, ars along the presumed strike of Fault \#2, found no offset in the base of the alluvium (Geomatrin 1995). 
A review of the caisson and foundation boring data from beneath Building 371 (a high density data grouping that may support shallow three dimensional mapping) suggests that the top of the 'bedrock' is an undulating surface. The lithologies are variable, as evidenced in the photographs. Therefore the high and low nature of the bedrock may be caused by differential lithologies, or they may have a structural origin. These data, on Figures 13 and 14, provide little new information, but do verify previous interpretations of the shallow subsurface using the same data (Geomatrix, 1995). It is not possible from this data to tie the undulations specifically to a structural or stratigraphic origin.

The plot of averaged $\mathrm{P}$-wave velocity for the borings underlying Building 371 describes a similar variability to the gamma curves and to the core descriptions in that a high level of variation is present. No definitive acoustically defined lithologic boundaries are present on this curve although Figure 17 shows the approximate tops of bedrock and Laramie as determined from the core descriptions. A smooth log normal regression curve, shown on Figure 17, demonstrates an increase in interval velocity with depth and shows the central tendency (maximum smoothing) of the geophysical log derived $\mathrm{P}$-wave velocities. The averaged $\mathrm{P}$-wave curve is generated from a subsurface sampling interval of approximately one inch and is a good comparison curve for expected velocities from surface measurements.

Figures 8 and 18 compares the averaged curve from boreholes 44092,43992 and 44192 with the P-wave curves determined from the Blackhawk data for Hole J (boring 1293, nearest Building 371) in ascending and descending mode, respectively. It is apparent from these graphs that many of the Blackhawk ascending and descending results do not correlate, nor correlate with the averaged curve. In only two cases, 35 feet and 110 feet, do the Blackhawk ascending and descending results agree, and in only seven measurements do the results fall within approximate proximity to the averaged curve. As compared to the averaged curve only 9 of the 20 total measurements are potentially significant. The log normal linear regression curve for the velocity values for the Blackhawk ascending data consistently vary between 800 to 1000 fps as compared to the averaged curve. The averaged Blackhawk descending data show velocity inversion with values at the surface approximately $1000 \mathrm{fps}$ faster than values at depth. Reviewing Figures 8 \& 18 suggests that the ascending and descending Blackhawk survey S-wave velocities from Hole J vary by 500 to $700 \mathrm{fps}$ with some disagreements as large as $2500 \mathrm{fps}$. Differences in ascending and descending values may be explained by a differing orientation of the receiving shuttle or by an inadequate clamping of the receiver to the boring wall. The reasons for the differences in velocities between the Blackhawk data and the geophysical log data are probably caused by the difference in acquisition technique. The Blackhawk data were acquired over a larger volume of lithology which averages inherent subsurface velocity differences. Because of this, it is difficult to determine where, within the volume of lithology evaluated, velocity contrasts occur. Additionally, Blackhawk data were 
WESTINGHOUSE SAVANNAH RIVER COMPANY

E\&CS SITE GEOTECHNICAL SERVICES DEPARTMENT

GEOLOGIC AND GEOTECHNICAL ASSESSMENT

RFETS BUILDING 371, ROCKY FLATS, COLORADO
WSRC-TR-95-0482

REVISION 0

December 13, 1995

Page 20

obtained from fewer sampling points. Therefore, there is more inherent variability because of less information for statistical evaluation.

\subsection{Summary}

The shallow investigation of the borings used in the Blackhawk report preclude a bottoms up geological investigation for Building 371. Figure 2 shows the relative thicknesses of the strata underlying the building and the depths of investigation of borings near the facility. Major geological contacts and acoustical contrasts are known to exist in the region but have not been mapped underneath or adjacent to Building 371. Shear wave data from the Blackhawk survey does not match data from the geophysical logs. The depth of investigation borfngs is insufficient to adequately establish a stratigraphic horizon versus seismic profile or model. Overall, existing data is inadequate for determining a subsurface shear wave profile versus definitive stratigraphic horizons, establishing P-wave attenuation contrasts for surface reflection seismic calibration, and for providing a defensible "bottoms up" geophysical log signature lithologic correlation. 
WESTINGHOUSE SAVANNAH RIVER COMPANY

E\&CS SITE GEOTECHNICAL SERVICES DEPARTMENT

GEOLOGIC AND GEOTECHNICAL ASSESSMENT

RFETS BUILDING 371, ROCKY FLATS, COLORADO
WSRC-TR-95-0482

REVISION 0

December 13, 1995

Page 21

\section{Appendix B}

\subsection{Shallow S-Wave Velocity Profile}

The objective of the evaluation was to validate the deep and shallow S-wave velocity profile. For discussion purposes, the bedrock "outcrop" is defined as that segment which has shear wave velocities of $2000 \mathrm{fps}$ or greater. The average shallow ( $<500 \mathrm{ft}$ ) shear-wave velocity profile for Building 371 was inferred from Vertical Seismic Profile (VSP) investigations conducted for EG\&G by Coleman Energy \& Environmental Systems - Blackhawk Geasciences Division (CEES-BGD) (1993, 1994). A total of eight boreholes were logged in the vicinity of Building 371 (Figure 1); boreholes B, C, D, E, F, G and J were logged in the first investigation conducted from July through August, 1993; hole L was completed in February, 1994. The VSP's were conducted with the objective of determining seismic P-and $\mathrm{S}$-wave velocities as a function of depth in each hole.

VSP's are typically conducted by monitoring vertically propagating P-and S-waves using specially designed borehole tools that measure vertical and two orthogonal horizontal components of ground motion. Seismic waves are normally excited at the top of the borehole by hammer blows. Data acquisition proceeds with the operator applying repeated vertical and horizontal hammer blows at each sensor depth. P-waves are enhanced by recording vertical motions with vertical hammer blows; S-waves are enhanced by recording horizontal motions from waves generated by hammer impacts on the end of a horizontal plank that is under vertical load. In practice, S-waves are further enhanced by recording motions from hammer blows in both horizontal directions. This action reverses the polarity of recorded motions and aids in wave identification. When the survey of each hole is completed, field notes describing the data acquisition process, acquisition parameters, geometry of source setup and tapes of sensor recordings are available for interpretation. Generally, visual play-outs of the recorded . data (either on computer screen or graphic hard-copy images) are used to manually "pick" the $\mathrm{P}$ - and S-wave arrivals and measure times. Times are adjusted for source horizontal offset distance, and then plotted and smoothed to derive depth "interval" velocities.

Review of the Blackhawk report indicated that standard industry practices were used in the data acquisition and data processing. Depths of boreholes C, D, F, and G limited interpretation to depths less than 30 feet. Holes B, E and $\mathrm{J}$ were interpreted to a depth range of approximately 110 - 140 feet. Hole $L$ was interpreted to a depth of nearly 500 feet. The Blackhawk report included spreadsheets of travel time "picks", and plots of travel-time and velocity-depth curves. The deeper profile interpretations (to depths of 130 feet or so) appear 
to be reasonably consistent from hole-to-hole. However, there are instances where the interpreted S-wave speeds exceed the $\mathrm{P}$-wave speeds without explanation or cause (Hole D).

Because the Blackhawk report did not include plots of raw wave-forms, it was not possible to review the quality of the phase arrival time "picks." Subsequent to the initial Blackhawk data reviews, raw data tapes and field notes were requested and received from Blackhawk for our analysis.

An independent interpretation of the data was made. A reinterpretation would, in principal, serve as a confirmatory review of the Blackhawk interpretation and differences found between the models could be used for analysis of variance in the predicted ground motions.

Wot that the selection of the S-phase arrival time is, to a degree, a matter of judgment and experience, so that typical VSP data, when independently reviewed, would always exhibit some differences between interpretations. Boreholes $\mathrm{J}$ and $\mathrm{L}$ were selected for independent interpretation because of their greater measurement depths, so that the depth of $2,000 \mathrm{fps}$ "bedrock" materials could be verified.

All raw digital VSP data transmitted to WSRC were given to the Earth Sciences Research Institute (ESRI) at the University of South Carolina. ESRI was charged with decoding and displaying the data both on hard-copy, and on computer graphics screen for visual measurement of arrival times. Several record sections were produced at various gain levels and enhancements. The record sections produced were independently interpreted by four experienced professionals (one DOE and three WSRC employees). S-wave picks were based on visual onset of reverse polarity motion observed along the complete record sections. Examples of these record sections are shown in Figures $20 \& 21$.

\subsection{J-Borehole VSP}

The Blackhawk J VSP had a "descending" and "ascending" data sample interval of 2 feet, 5 feet and 10 feet at depth ranges of $2-20^{\prime}, 20-100^{\prime}$, and 100-140' respectively (see Figure 6 for the Blackhawk interpretation). Blackhawk made twenty-nine S-wave picks using both data acquisition directions. The clearest signals were recorded on the "ascending" direction record section from the J-borehole VSP. These signals are reproduced in Figure 20. Where available, the plotted signals show both polarities for both horizontal components at each recording depth. The $S$-wave arrival is relatively unambiguous at many depths. Highfrequency noise is only apparent on the deepest recordings. WSRC made sixteen S-wave arrival picks with a high degree of confidence in the $2-140 \mathrm{ft}$ depth interval on the "ascending" record direction. WSRC could not make picks at all depths because of uncertainty in arrival time pick. Because of the smaller number of picks, the WSRC 
WESTINGHOUSE SAVANNAH RIVER COMPANY

WSRC-TR-95-0482

E\&CS SITE GEOTECHNICAL SERVICES DEPARTMENT

REVISION 0

GEOLOGIC AND GEOTECHNICAL ASSESSMENT

December 13, 1995

RFETS BUILDING 371, ROCKY FLATS, COLORADO

Page 23

reinterpretation has somewhat poorer resolution (Figure 4) than the Blackhawk results. Interval velocities estimated from the travel-times range from about $450 \mathrm{fps}$ to about 1600 fps. The average interval velocities are within $12-50 \%$ of the Blackhawk J-borehole velocities (Figure 4).

\subsection{L-Borehole VSP}

The L VSP had a "descending" and "ascending" data sample interval of $5 \mathrm{ft}$ and $20 \mathrm{ft}$ at depth ranges of $40-150 \mathrm{ft}$ and $150-500 \mathrm{ft}$ respectively (see Figure 7 for the Blackhawk interpretation). The "ascending" recording direction exhibited the clearest signals from Lborehole VSP (Figure 21). The plotted signals show both polarities for both horizontal cemponents at each recording depth, where available. The S-wave arrival is relatively unambiguous at shallower depths ( $<80 \mathrm{ft}$ ), and except for the $180-240 \mathrm{ft}$ depth range, is contained in other signal generated tube-wave or other signal generated noise.

Because of difficulty in finding the S-wave arrival in many portions of the L-borehole record sections, only fifteen S-wave picks could be made in the $40-500 \mathrm{ft}$ depth interval (Blackhawk made over twenty-two S-wave picks in each direction). The WSRC L-borehole reinterpretation has poor resolution (Figure 5). No S-wave arrivals could be picked with high degree of confidence in the depth range of about $80-180 \mathrm{ft}$. If the $180-240 \mathrm{ft}$ travel-time picks are valid, then $2,000 \mathrm{fps}$ speeds are expected between depths of about $80 \mathrm{ft}$ and $180 \mathrm{ft}$. As mentioned above, this depth is critical to the site response and should be resolved. Below $240 \mathrm{ft}$, only two arrivals could be selected (at about 360 and $500 \mathrm{ft}$ ). These two "picks" are widely spaced in depth, making them very questionable because the S-wave form cannot be followed down the section. Where interval velocities could be inferred, the results are within $8-21 \%$ of Blackhawk L-borehole interpreted values (Figure 5). The Blackhawk interpretation for the L-borehole VSP could not be validated.

\subsection{Summary}

The techniques used to collect and process the original VSP data were industry standard. Independent analysis of data collected in borehole $\mathrm{L}$ indicate that $\mathrm{S}$-waves could not be unambiguously selected at many sensor depths, resulting in relatively small number of $S$ wave picks, particularly for deeper portions of the section. The inability to identify S-waves could be caused by: 1) high rates of energy loss (damping) of the direct shear-wave 2) scattering of signal 3) high background noise levels 4) stimulation of interfering borehole tube wave or 5) a combination of the above causes. The depth and magnitude of the significant velocity contrasts reported by Blackhawk could not be independently verified. However, where velocity intervals could be estimated with confidence, average velocities were within about $10-50 \%$ of values reported by Blackhawk, see Figures 4 and 5 . 
WESTINGHOUSE SAVANNAH RIVER COMPANY

E\&CS SITE GEOTECHNICAL SERVICES DEPARTMENT

GEOLOGIC AND GEOTECHNICAL ASSESSMENT

RFETS BUILDING 371, ROCKY FLATS, COLORADO
WSRC-TR-95-0482

REVISION 0

December 13, 1995

Page 24

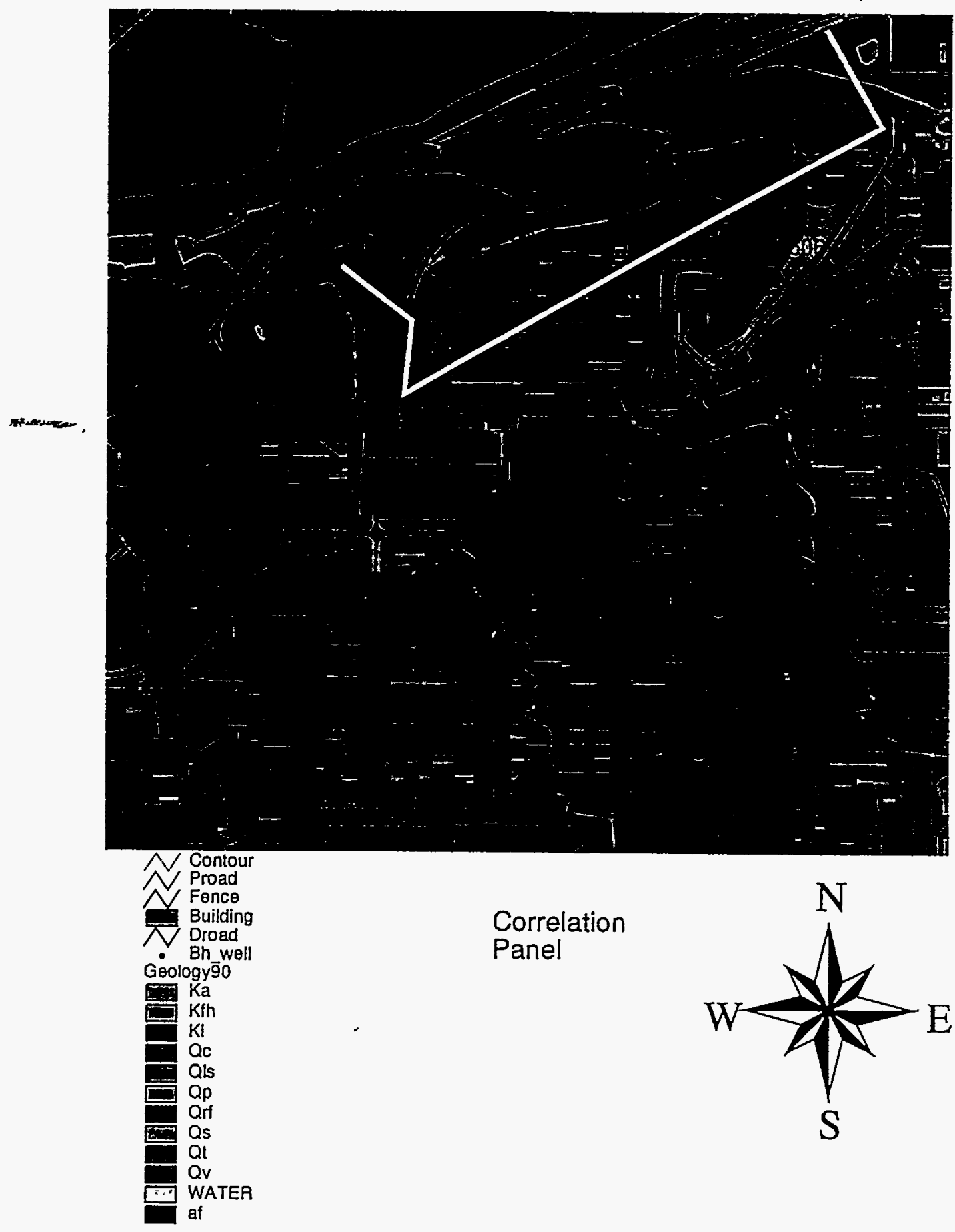

Figure 1

Boreholes Adjacent to Building 371 
WESTINGHOUSE SAVANNAH RIVER COMPANY

E\&CS SITE GEOTECHNICAL SERVICES DEPARTMENT

GEOLOGIC AND GEOTECHNICAL ASSESSMENT

RFETS BUILDING 371, ROCKY FLATS, COLORADO
WSRC-TR-95-0482

REVISION 0

December 13, 1995

Page 25

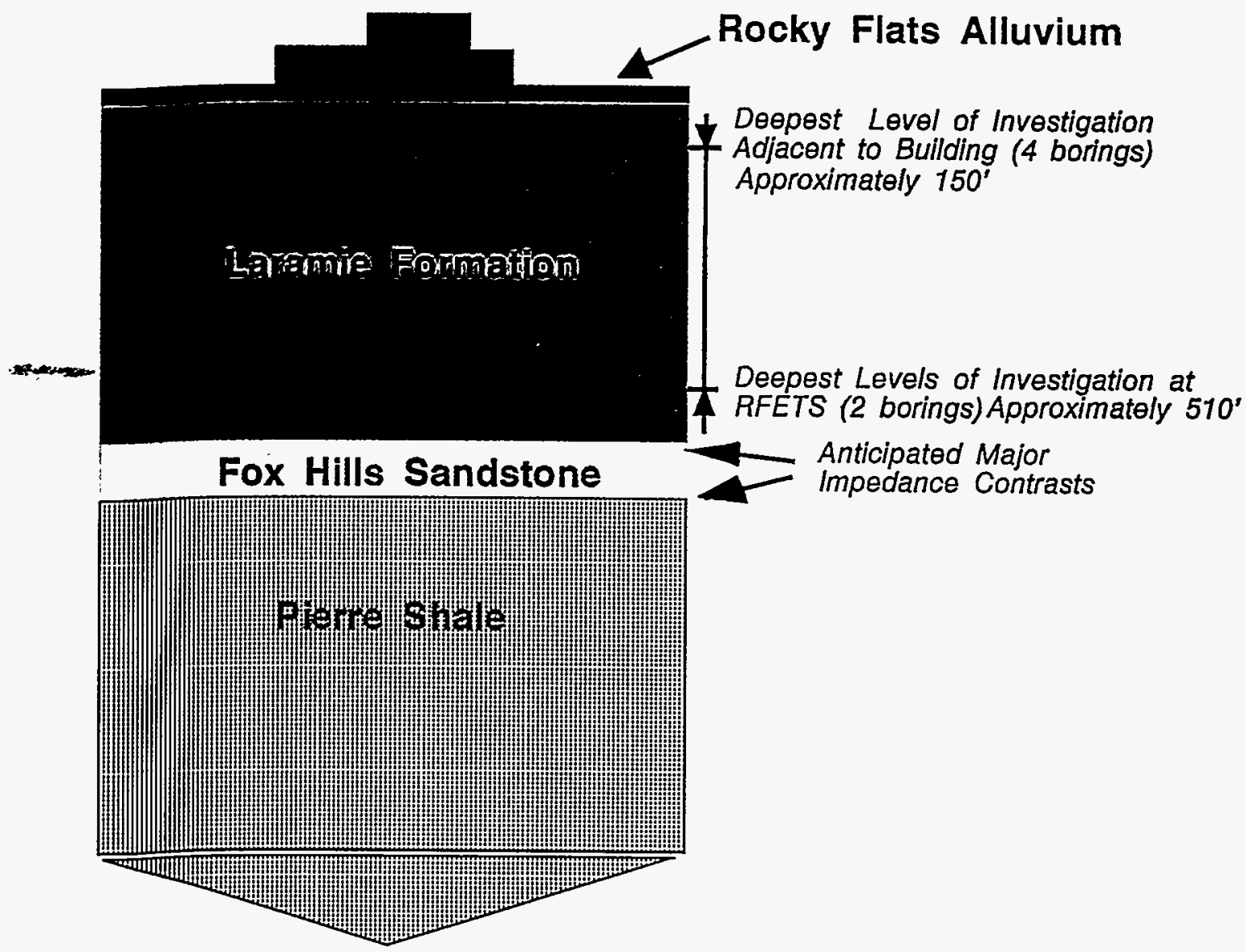

Relative Depths of Investigation Under Building 371 (depth uncertainty varies according to the depth ranges on the Generalized Stratigraphic Column for the Rocky Flats Area)

Figure 2

Depth Limits of Investigation Adjacent to Building 371 


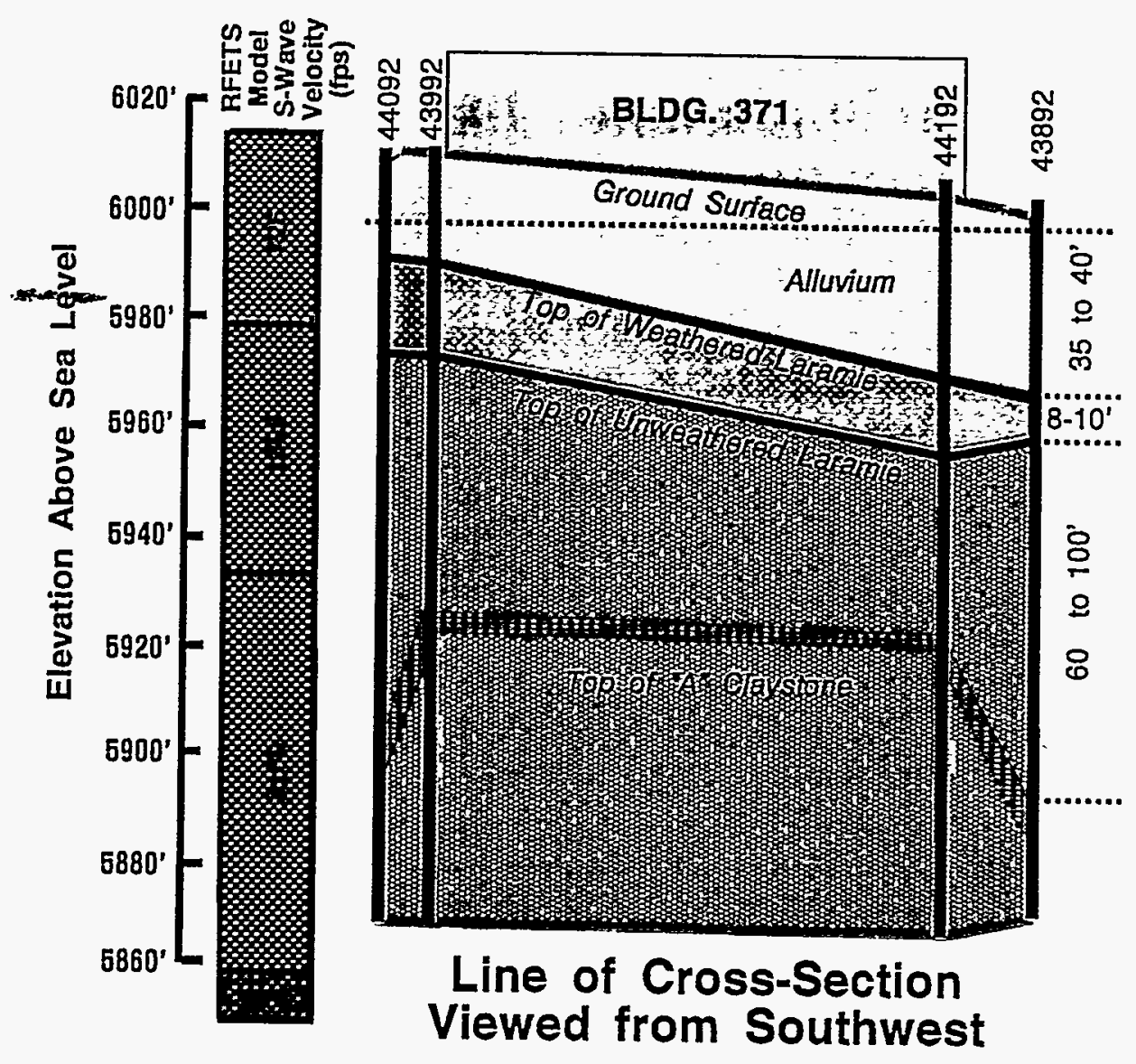

Figure 3

Shallow Stratigraphy Under Building 371 
WESTINGHOUSE SAVANNAH RIVER COMPANY

WSRC-TR-95-0482

E\&CS SITE GEOTECHNICAL SERVICES DEPARTMENT .

REVISION 0

GEOLOGIC AND GEOTECHNICAL ASSESSMENT

December 13, 1995

RFETS BUILDING 371, ROCKY FLATS, COLORADO

Page 27

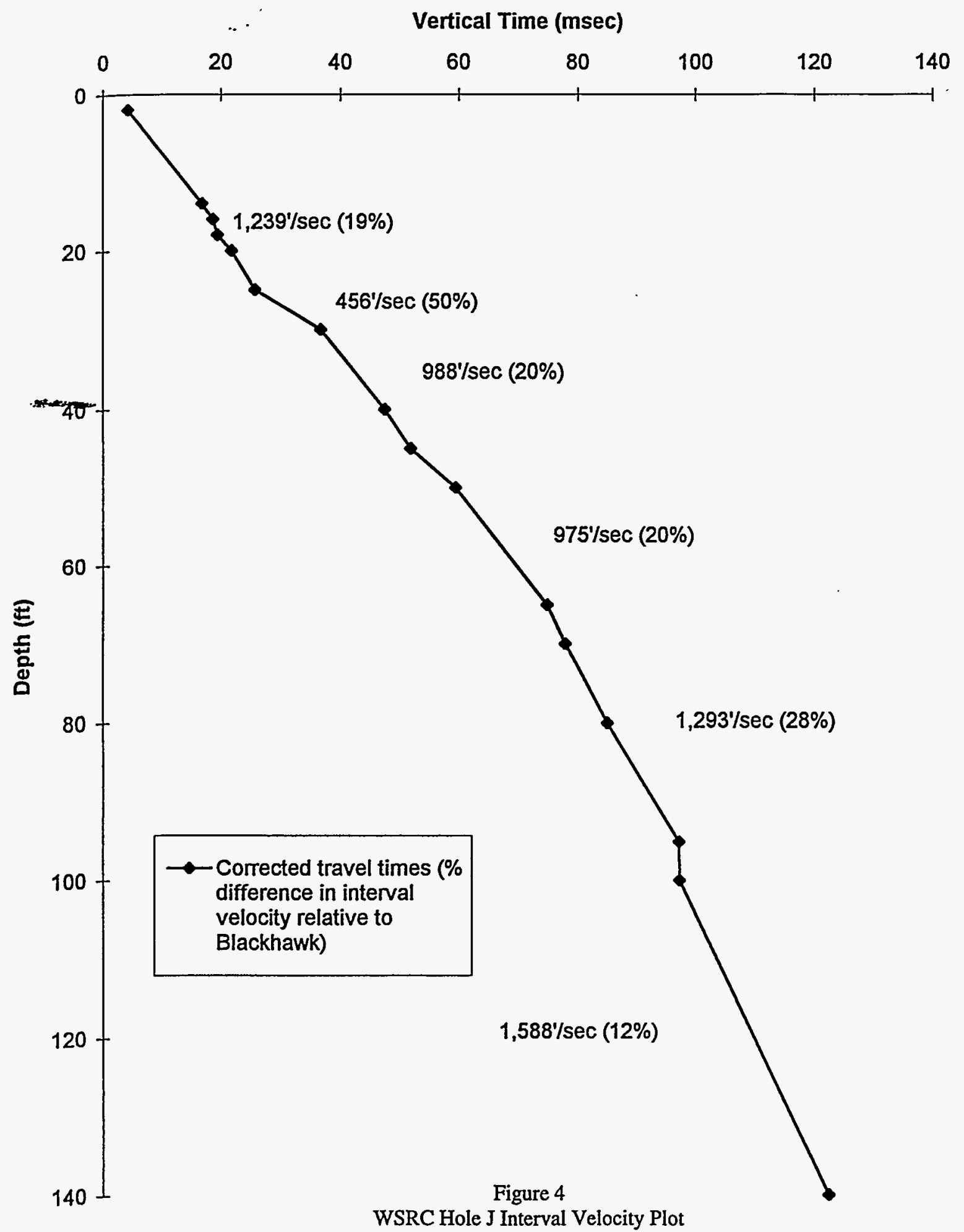


WESTINGHOUSE SAVANNAH RIVER COMPANY

E\&CS SITE GEOTECHNICAL SERVICES DEPARTMENT

GEOLOGIC AND GEOTECHNICAL ASSESSMENT

RFETS BUILDING 371, ROCKY FLATS, COLORADO
WSRC-TR-95-0482

REVISION 0

December 13, 1995

Page 28

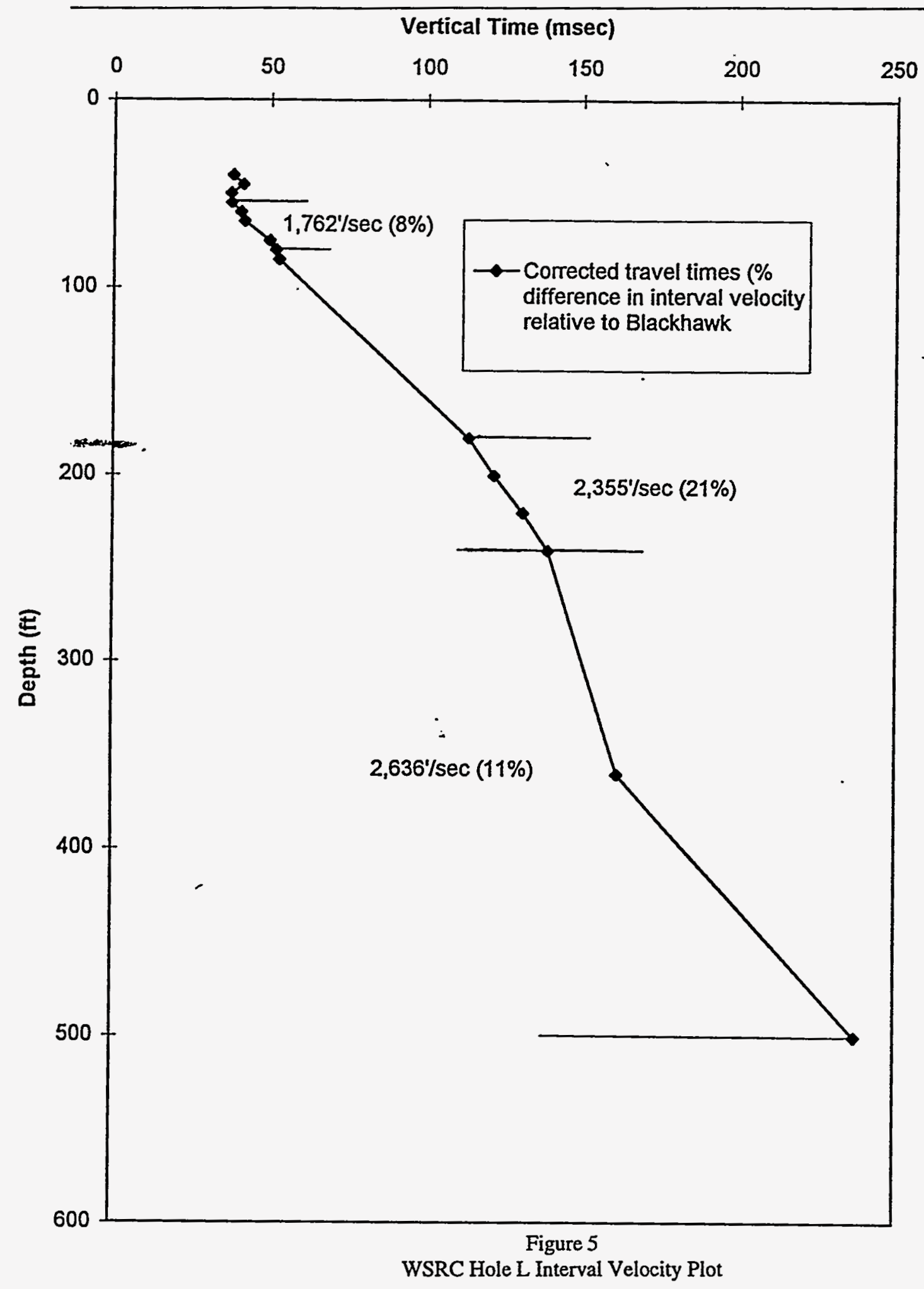


WESTINGHOUSE SAVANNAH RIVER COMPANY

E\&CS SITE GEOTECHNICAL SERVICES DEPARTMENT

GEOLOGIC AND GEOTECHNICAL ASSESSMENT

RFETS BUILDING 371, ROCKY FLATS, COLORADO
WSRC-TR-95-0482

REVISION 0

December 13, 1995

Page 29

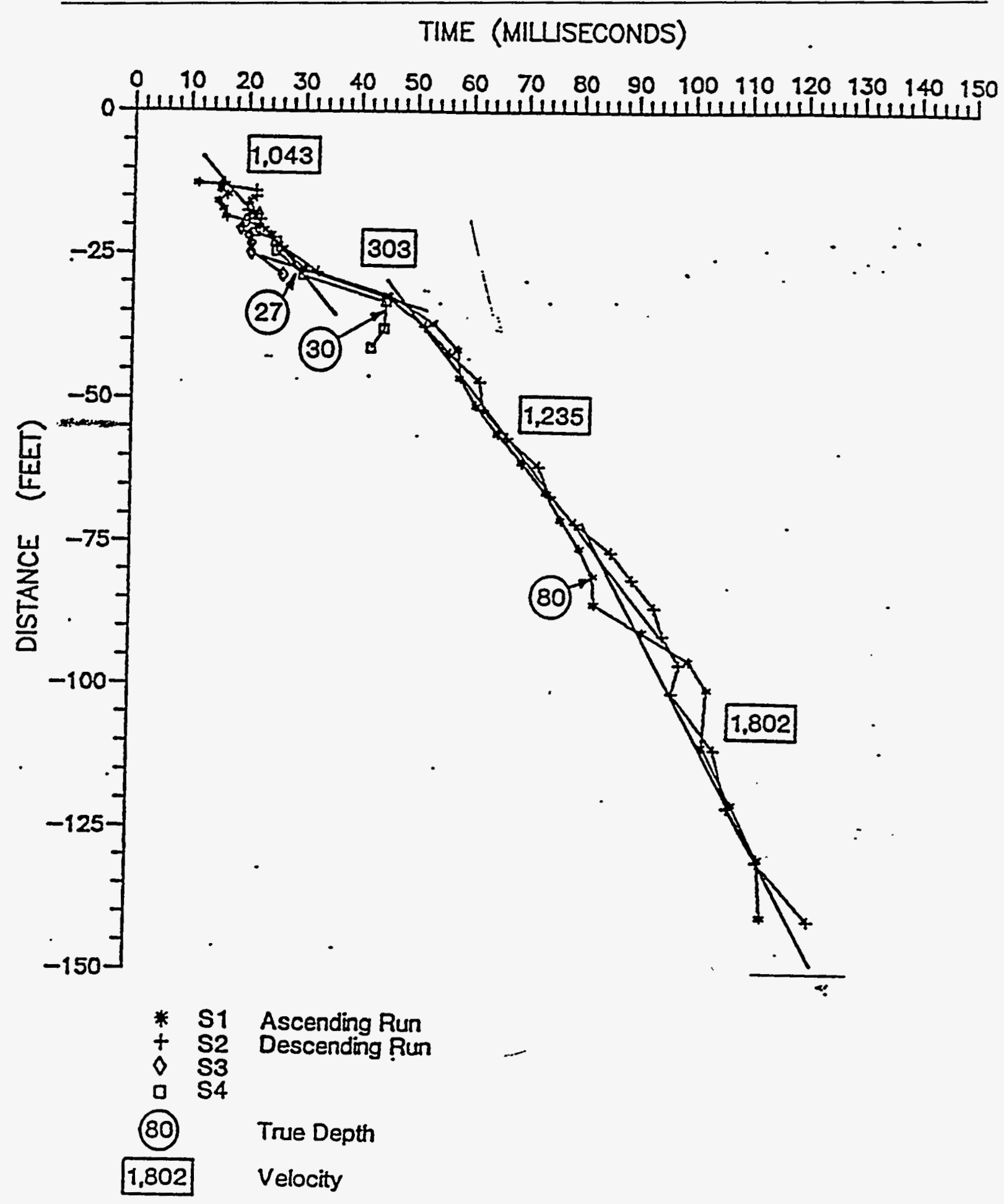

Figure 6

Blackhawk Hole-J Shear Wave Travel Time Curves 
WESTINGHOUSE SAVANNAH RIVER COMPANY

E\&CS SITE GEOTECHNICAL SERVICES DEPARTMENT

GEOLOGIC AND GEOTECHNICAL ASSESSMENT

RFETS BUILDING 371, ROCKY FLATS, COLORADO
WSRC-TR-95-0482

REVISION 0

December 13, 1995

Page 30

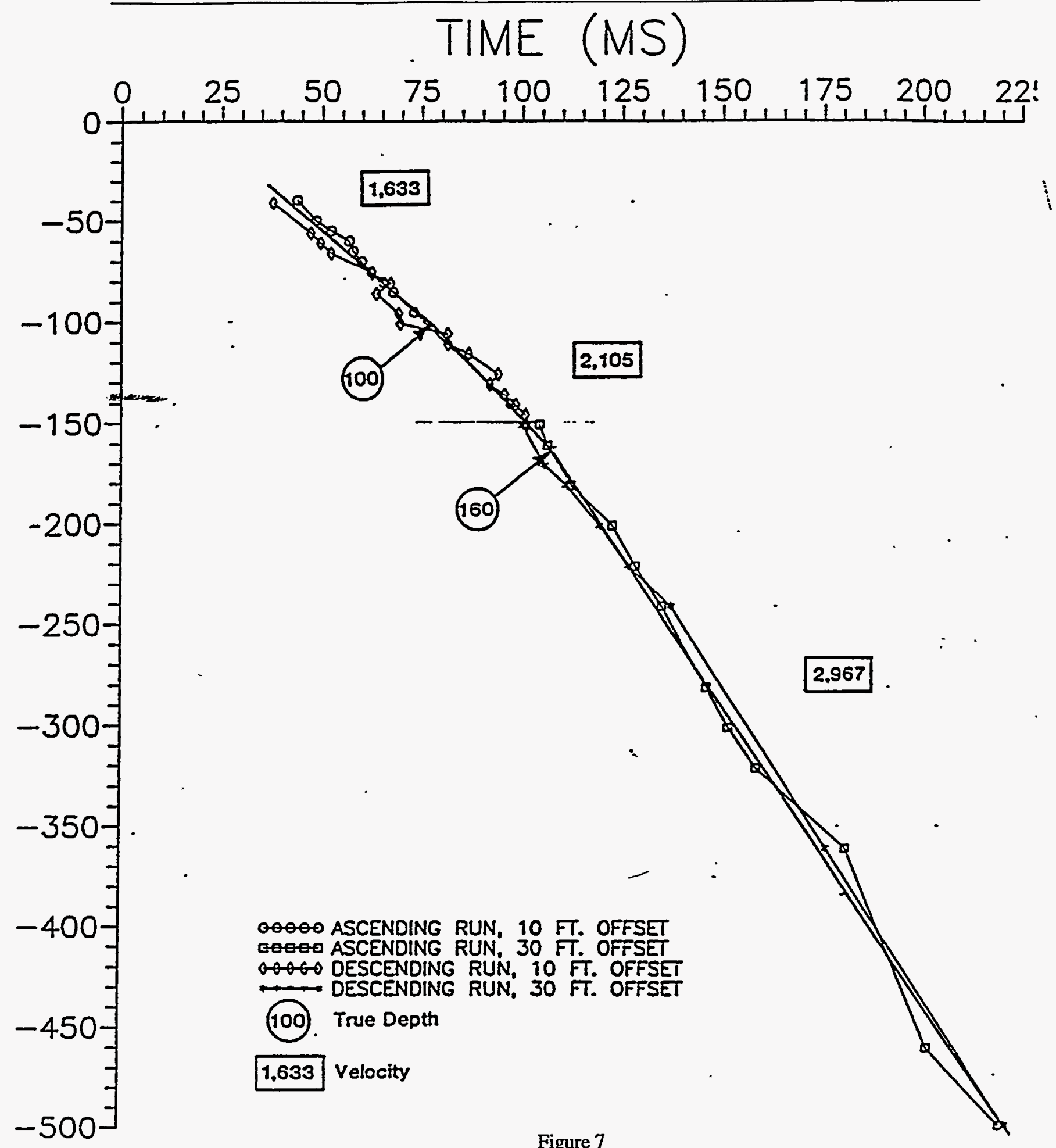

Figure 7

Blackhawk Hole-L Shear Wave Travel Time Curves 


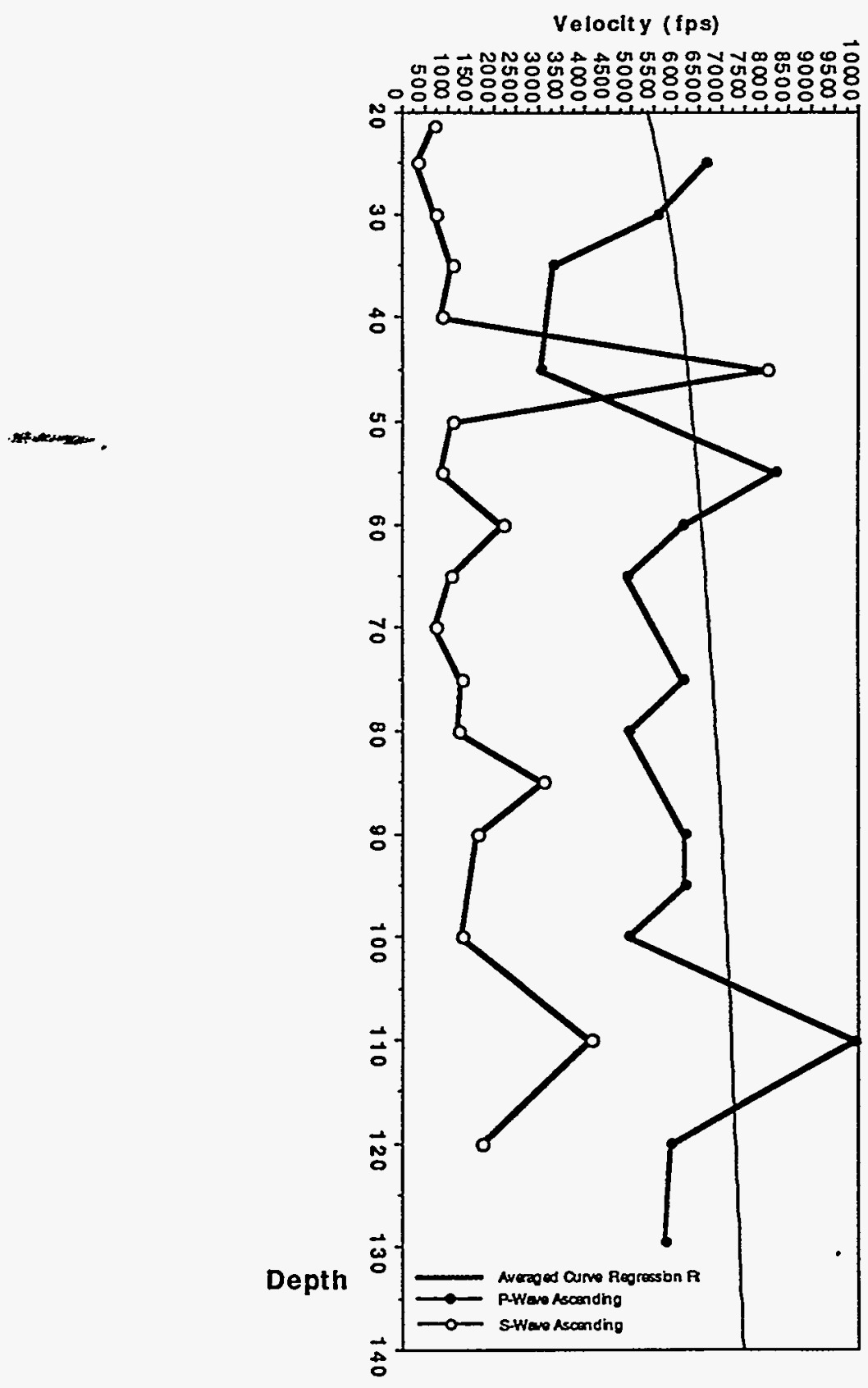

Figure 8

Blackhawk Hole-J Ascending P- \& S-Wave Data Versus Averaged P-Wave Curve 
WESTINGHOUSE SAVANNAH RIVER COMPANY

E\&CS SITE GEOTECHNICAL SERVICES DEPARTMENT

GEOLOGIC AND GEOTECHNICAL ASSESSMENT

RFETS BUILDING 371, ROCKY FLATS, COLORADO
WSRC-TR-95-0482

REVISION 0

December 13, 1995

Page 32

G/Gmax Curves Used by RFETS (1994) after EPRI (1993)

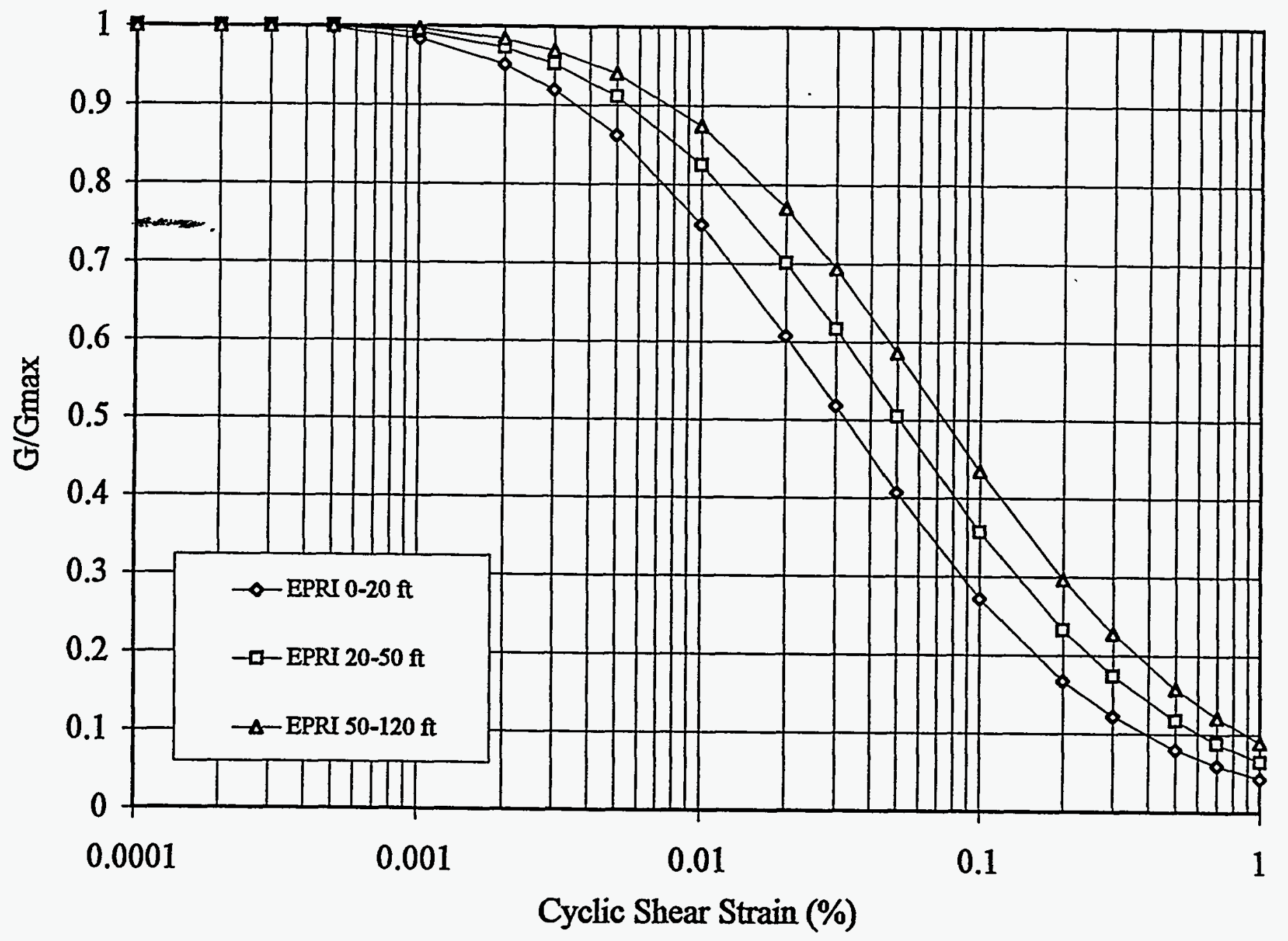

Figure 9

G/GMax Curves Used by RFETS (1994) after EPRI (1993) 
WESTINGHOUSE SAVANNAH RIVER COMPANY

E\&CS SITE GEOTECHNICAL SERVICES DEPARTMENT

GEOLOGIC AND GEOTECHNICAL ASSESSMENT

RFETS BUILDING 371, ROCKY FLATS, COLORADO
WSRC-TR-95-0482

REVISION 0

December 13, 1995

Page 34

Recommended Range of G/Gmax for Claystone and Alluvial Gravels (after EPRI Clay Curves $(30<\mathrm{PI}<50)$ and Rollins et al. Gravel Curves)

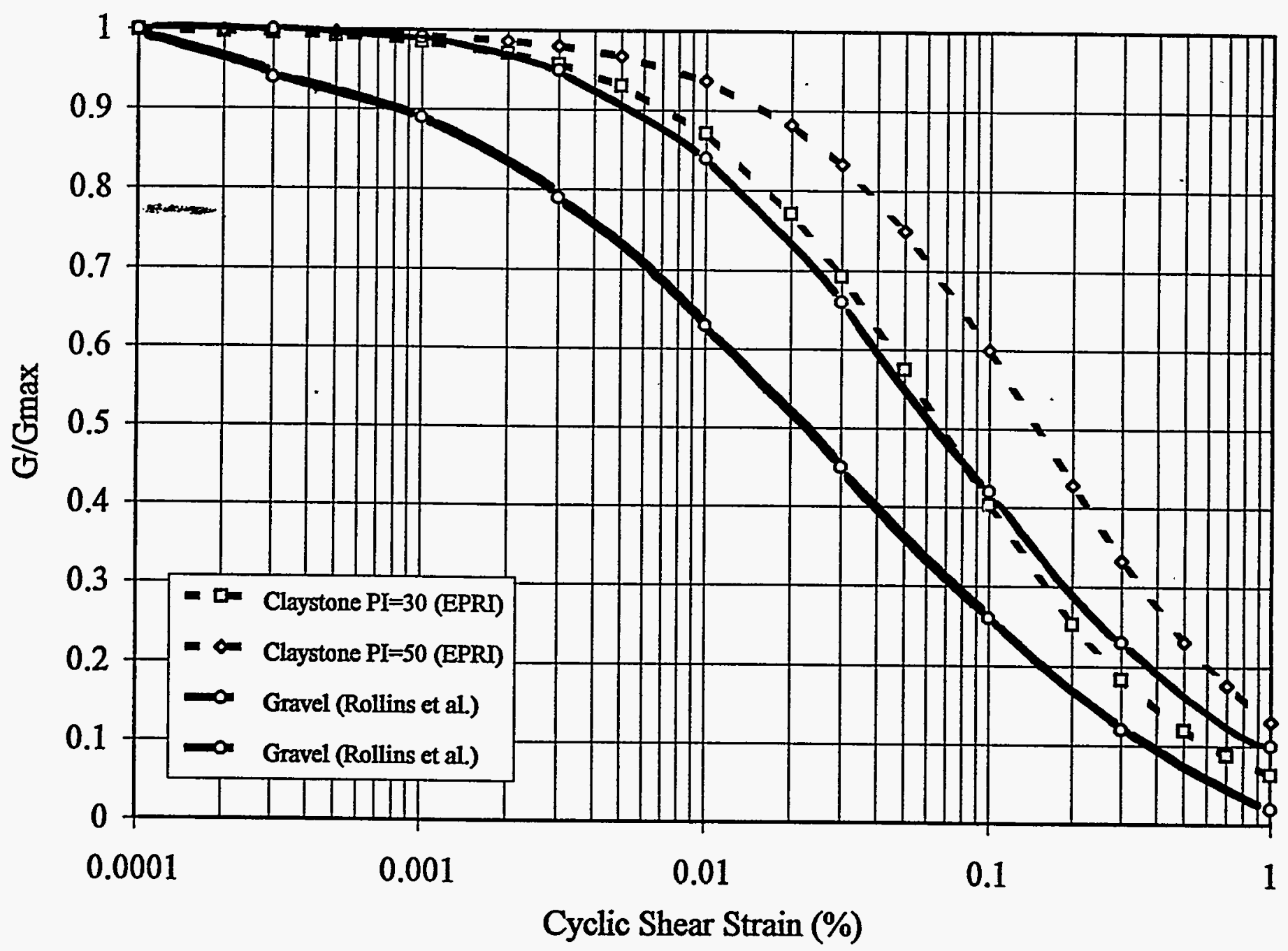

Figure 11

Recommended Range of G/Gmax for Claystone and Alluvial Gravels 
WESTINGHOUSE SAVANNAH RIVER COMPANY

E\&CS SITE GEOTECHNICAL SERVICES DEPARTMENT

GEOLOGIC AND GEOTECHNICAL ASSESSMENT

RFETS BUILDING 371, ROCKY FLATS, COLORADO
WSRC-TR-95-0482

REVISION 0

December 13, 1995

Page 35

Recommended Range of Damping for Claystone and Alluvial Gravels (after EPRI Clay Curves $(30<\mathrm{PI}<50)$ and Rollins et al. Gravel Curve)

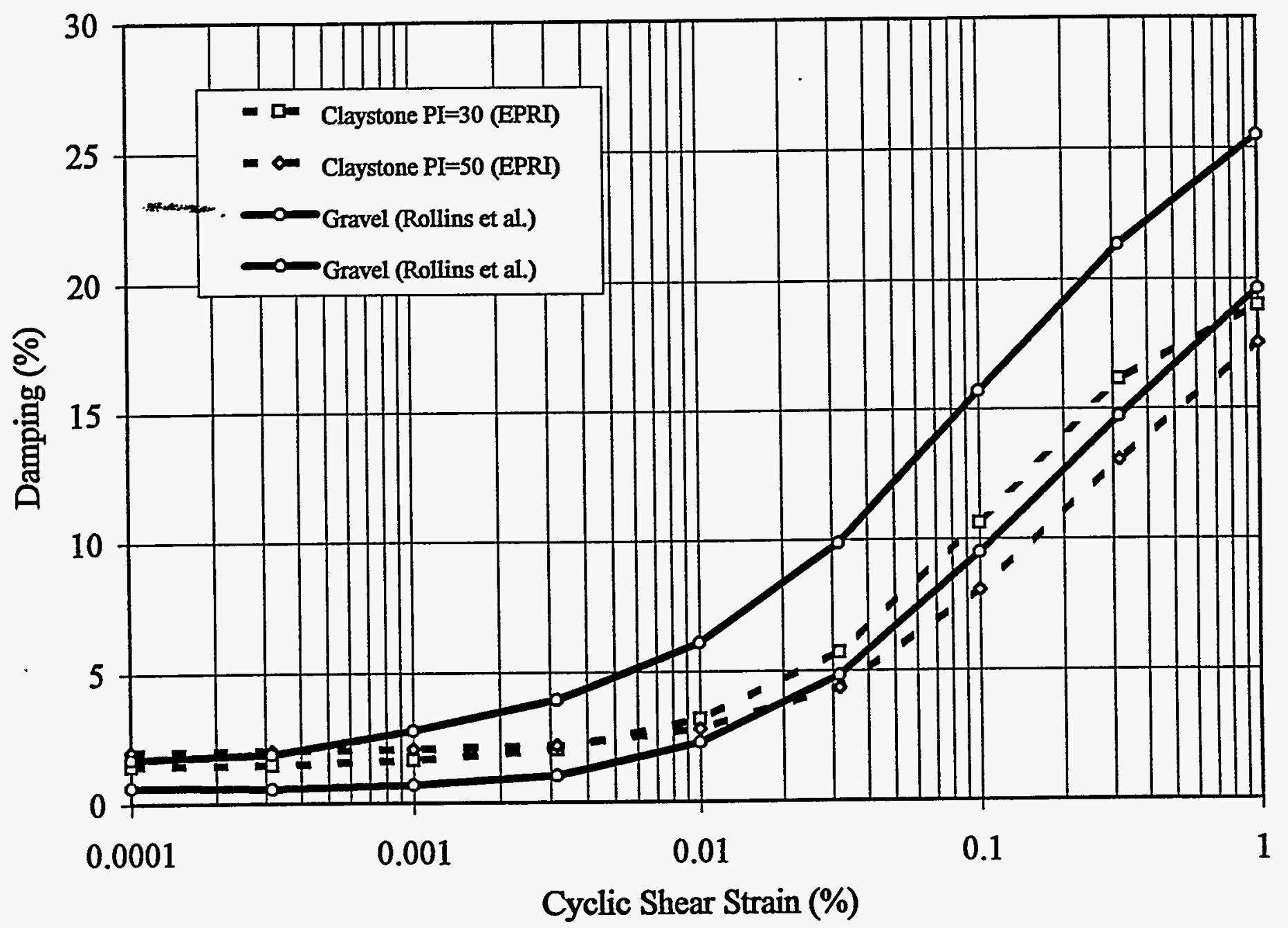

Figure 12

Recommended Range of Damping for Claystone and Alluvial Gravels 
WESTINGHOUSE SAVANNAH RIVER COMPANY

E\&CS SITE GEOTECHNICAL SERVICES DEPARTMENT

GEOLOGIC AND GEOTECHNICAL ASSESSMENT

RFETS BUILDING 371, ROCKY FLATS, COLORADO
WSRC-TR-95-0482

REVISION 0

December 13, 1995

Page 36

\section{BUILDING 371 FOUNDATION BOREHOLE TOP OF "VERY HARD CLAY"}

FROM CORE OESCRIPTIONS, 1972 WOODWARD-CLEVENGER REPORT

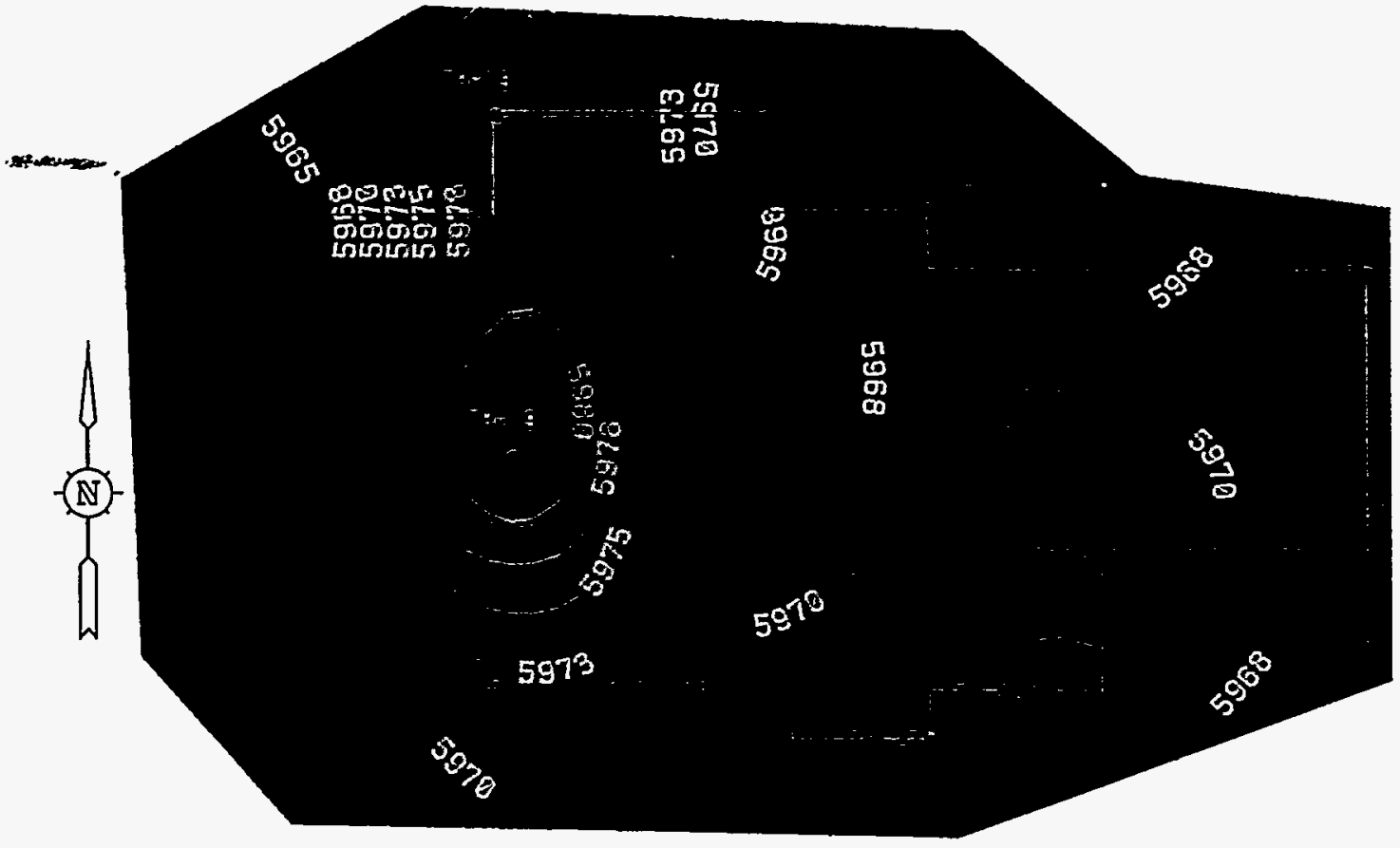

BUILOING 37 OUTLINE 
WESTINGHOUSE SAVANNAH RIVER COMPANY E\&CS SITE GEOTECHNICAL SERVICES DEPARTMENT GEOLOGIC AND GEOTECHNICAL ASSESSMENT RFETS BUILDING 371, ROCKY FLATS, COLORADO
WSRC-TR-95-0482

REVISION 0

December 13, 1995

Page 37

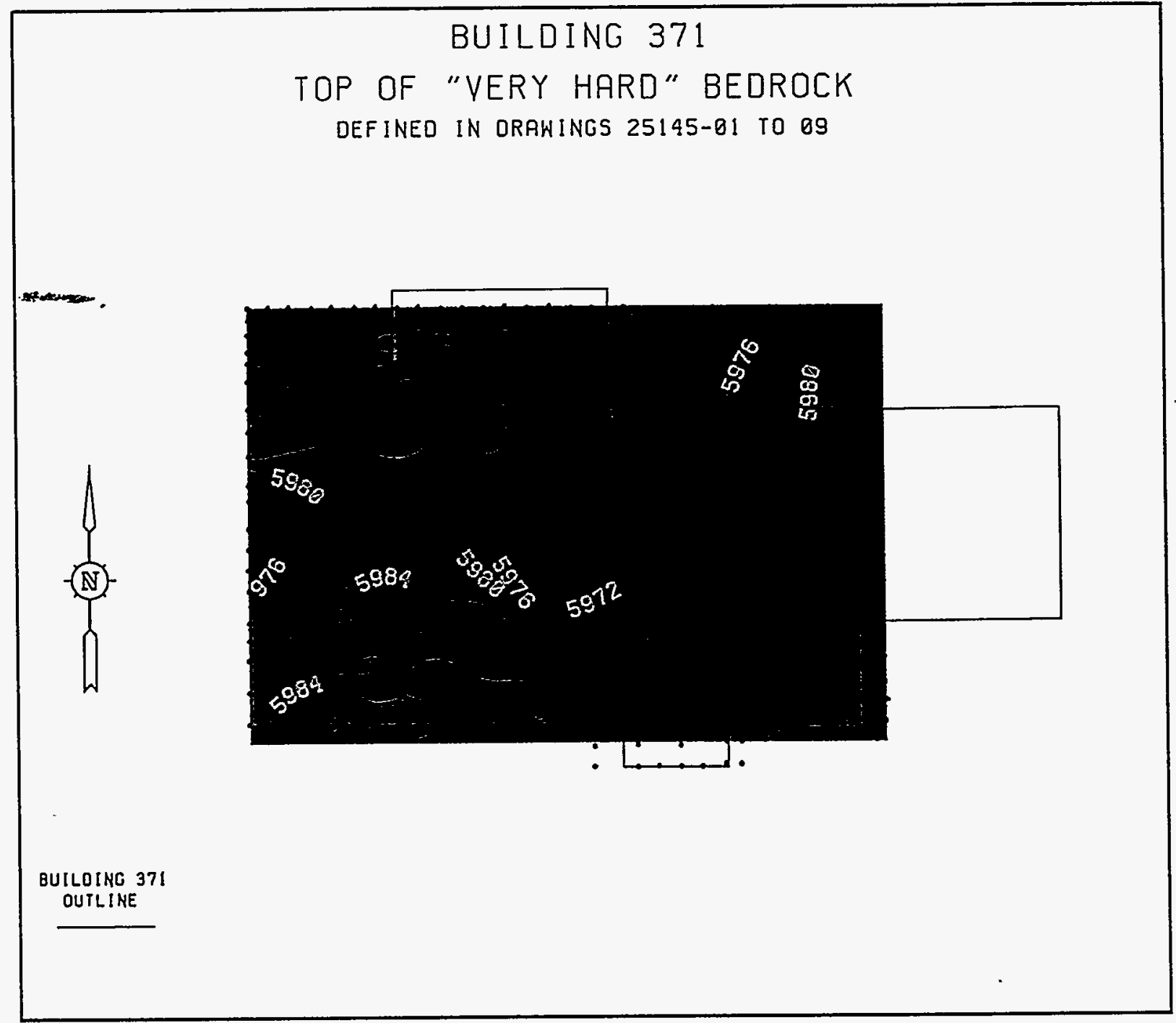

Figure 14

Building 371 Caisson Data Top of "Very Hard Bedrock" 
WESTINGHOUSE SAVANNAH RIVER COMPANY

E\&CS SITE GEOTECHNICAL SERVICES DEPARTMENT

GEOLOGIC AND GEOTECHNICAL ASSESSMENT

RFETS BUILDING 371, ROCKY FLATS, COLORADO
WSRC-TR-95-0482

REVISION 0

December 13, 1995

Page 38

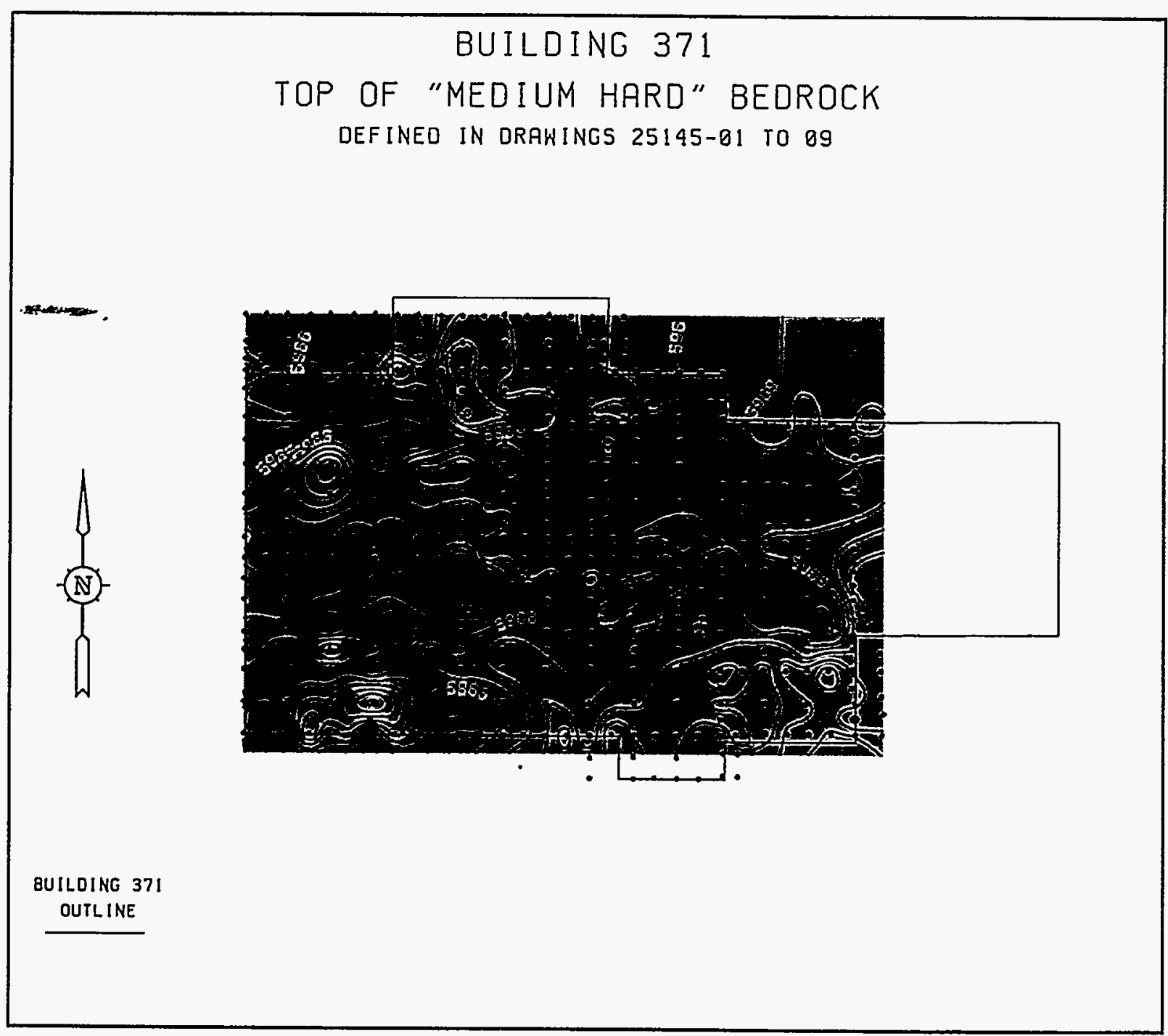

Figure 15

Building 371 Caisson Data Top of "Medium Hard Bedrock" 
Foldout 


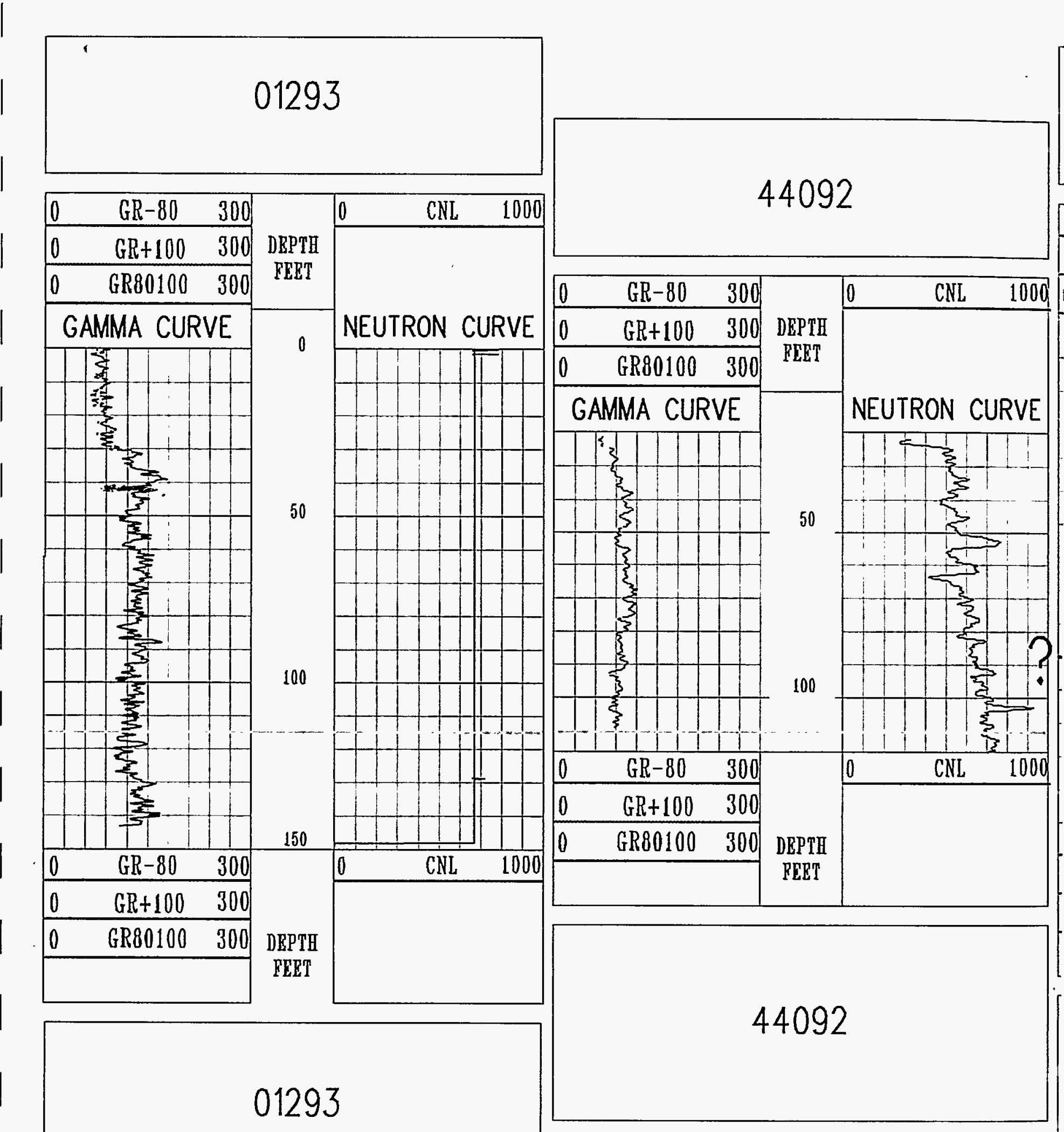




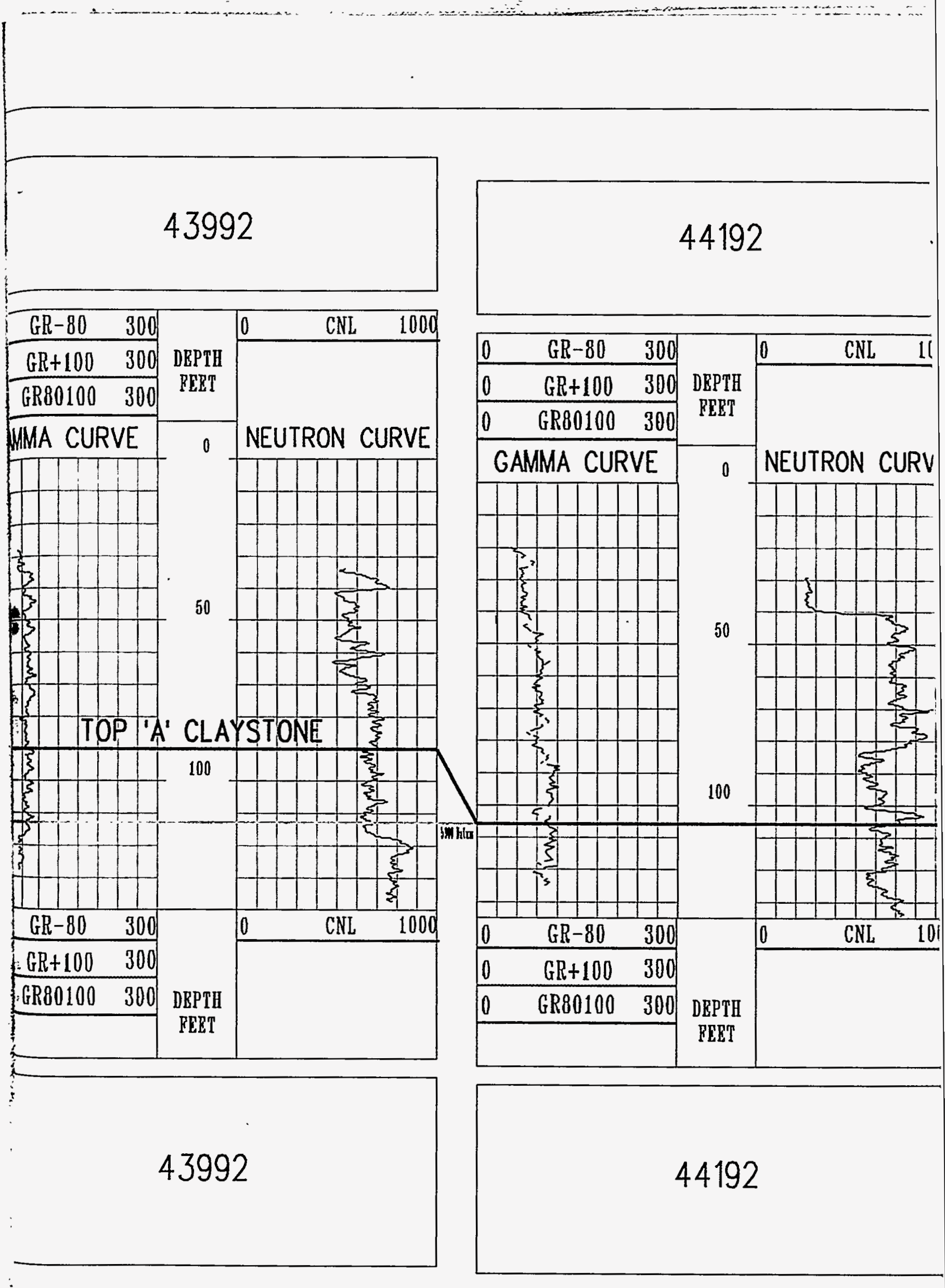



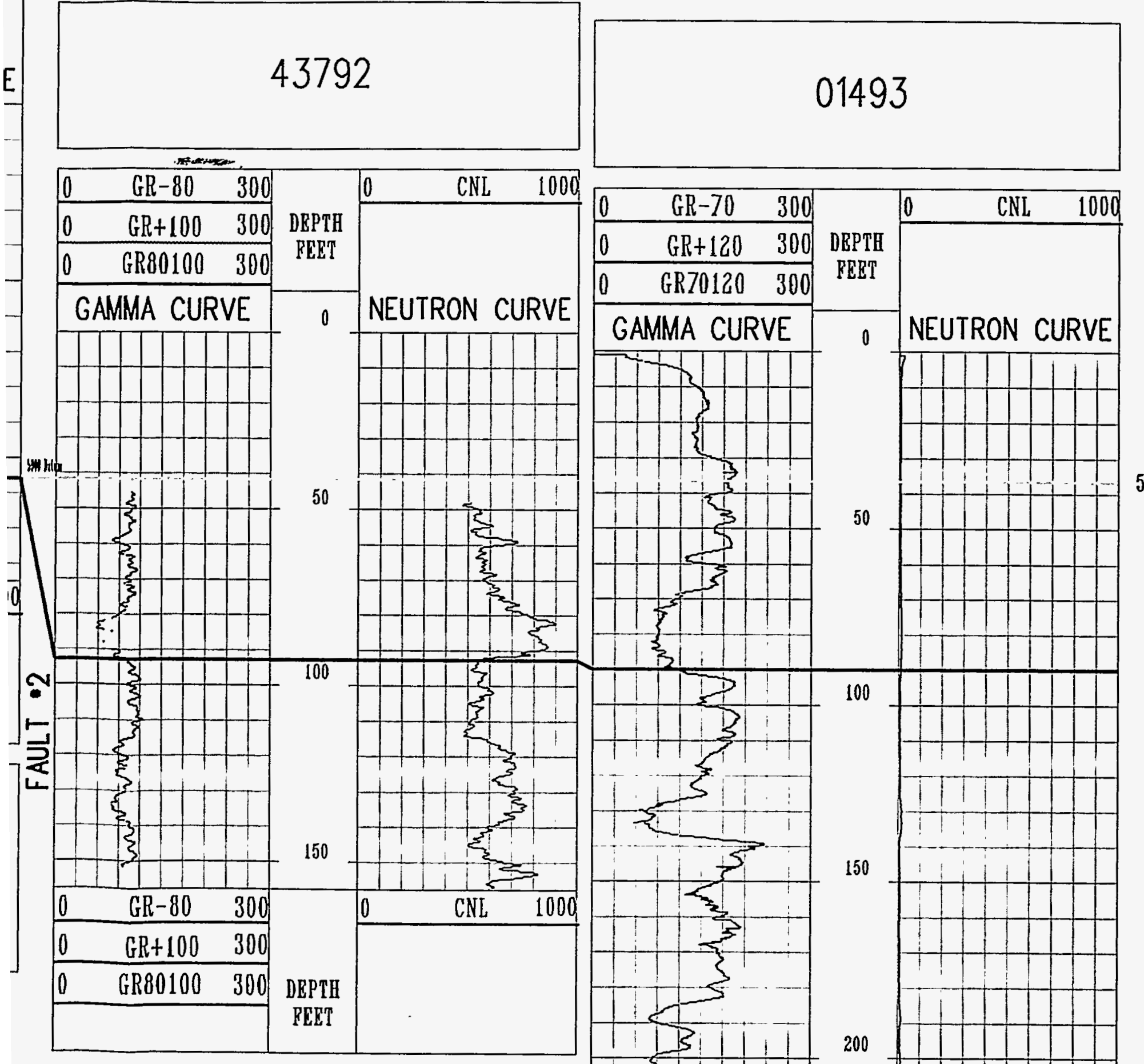

$5900 \mathrm{Da}$
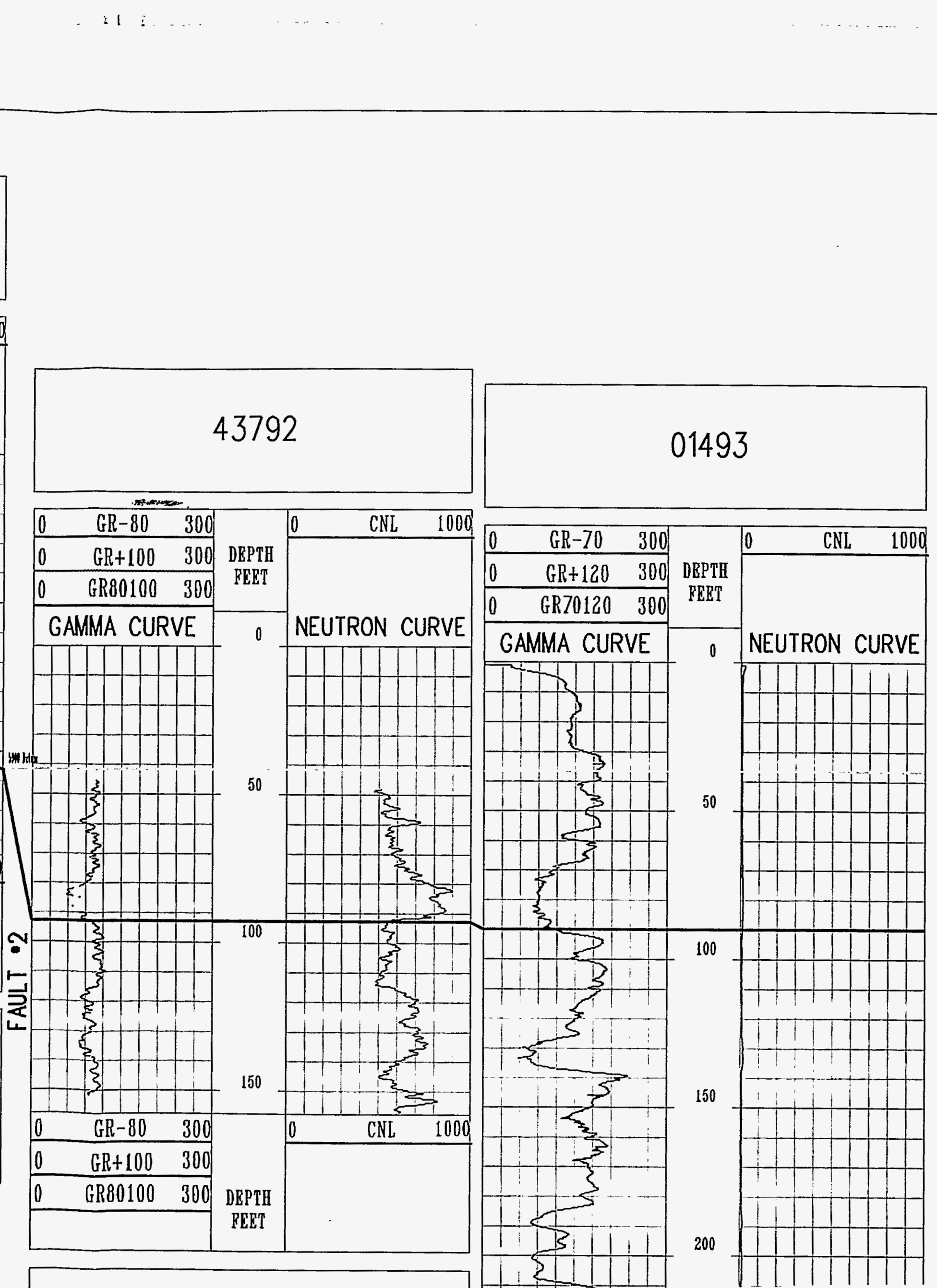


\section{LEGEND}

SANDY SILTSTONE WITH GREATER

THAN 25\% VERY FINE GRAINED SAND

CLAYSTONE , GREATER THAN $90 \%$ CLAY

SILTY CLAYSTONE

5. $\quad$ - 900 DATUM

\begin{tabular}{|c|c|c|c|}
\hline DWG NO. ROCKY7.DGN & $\begin{array}{r}\text { REV.NO. } \\
\emptyset\end{array}$ & $\begin{array}{r}\text { REV. DATE } \\
12-6-95\end{array}$ & ${ }^{\text {AREA }}$ ROCKY FLATS \\
\hline \multicolumn{4}{|c|}{$\begin{array}{c}\text { ROCKY FLATS SEISMIC STUDY } \\
\text { BLDG. } 371 \\
\text { STRATIGRAPHY AND STRUCTURE } \\
\text { CORRELATION PANEL }\end{array}$} \\
\hline $\begin{array}{l}\text { CREATED BY } \\
\text { JOHN SHERRILL }\end{array}$ & $\begin{array}{l}\text { DATE } \\
12-6-95\end{array}$ & $\begin{array}{l}\text { APPROVED BY } \\
\text { NA }\end{array}$ & \begin{tabular}{|l} 
DATE \\
NA \\
\end{tabular} \\
\hline $\begin{array}{l}\text { PREPARED BY } \\
\text { DOUG WYATT }\end{array}$ & $\begin{array}{l}\text { DATE } \\
12-6-95\end{array}$ & $\begin{array}{l}\text { APPROVED BY } \\
\text { NA }\end{array}$ & $\begin{array}{l}\text { DATE } \\
\text { NA }\end{array}$ \\
\hline $\begin{array}{l}\text { DRAWN BY } \\
\text { JIM HANEY }\end{array}$ & \begin{tabular}{|l} 
DATE \\
$12-6-95$
\end{tabular} & $\begin{array}{l}\text { APPROVED BY } \\
\text { NA }\end{array}$ & \begin{tabular}{|l|} 
DATE \\
NA \\
\end{tabular} \\
\hline $\begin{array}{l}\text { APPROVED BY } \\
\text { NA }\end{array}$ & \begin{tabular}{|l} 
DATE \\
NA
\end{tabular} & $\begin{array}{l}\text { APPROVED BY } \\
\text { NA }\end{array}$ & \begin{tabular}{|l} 
DATE \\
NA
\end{tabular} \\
\hline
\end{tabular}



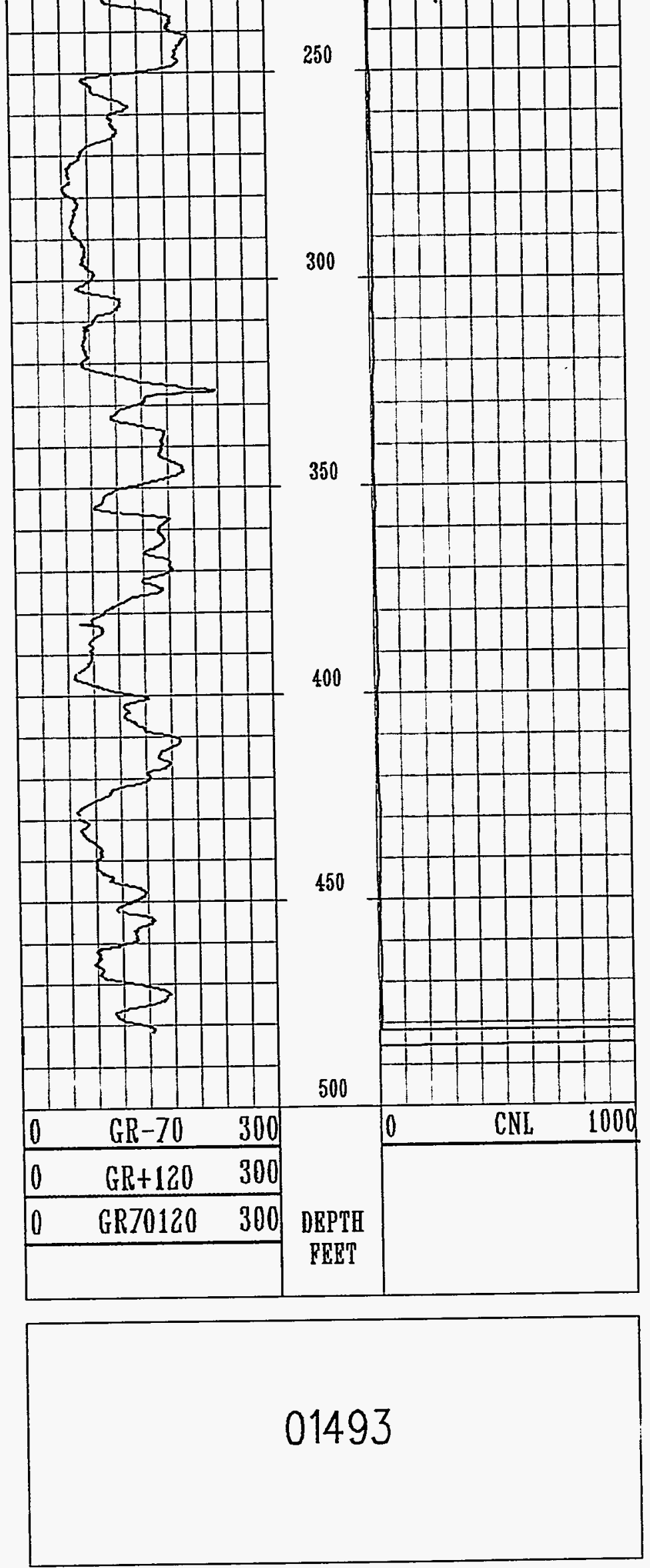
WSRC-TR-95-0482

E\&CS SITE GEOTECHNICAL SERVICES DEPARTMENT REVISION 0

GEOLOGIC AND GEOTECHNICAL ASSESSMENT

December 13, 1995

RFETS BUILDING 371, ROCKY FLATS, COLORADO

Page 40

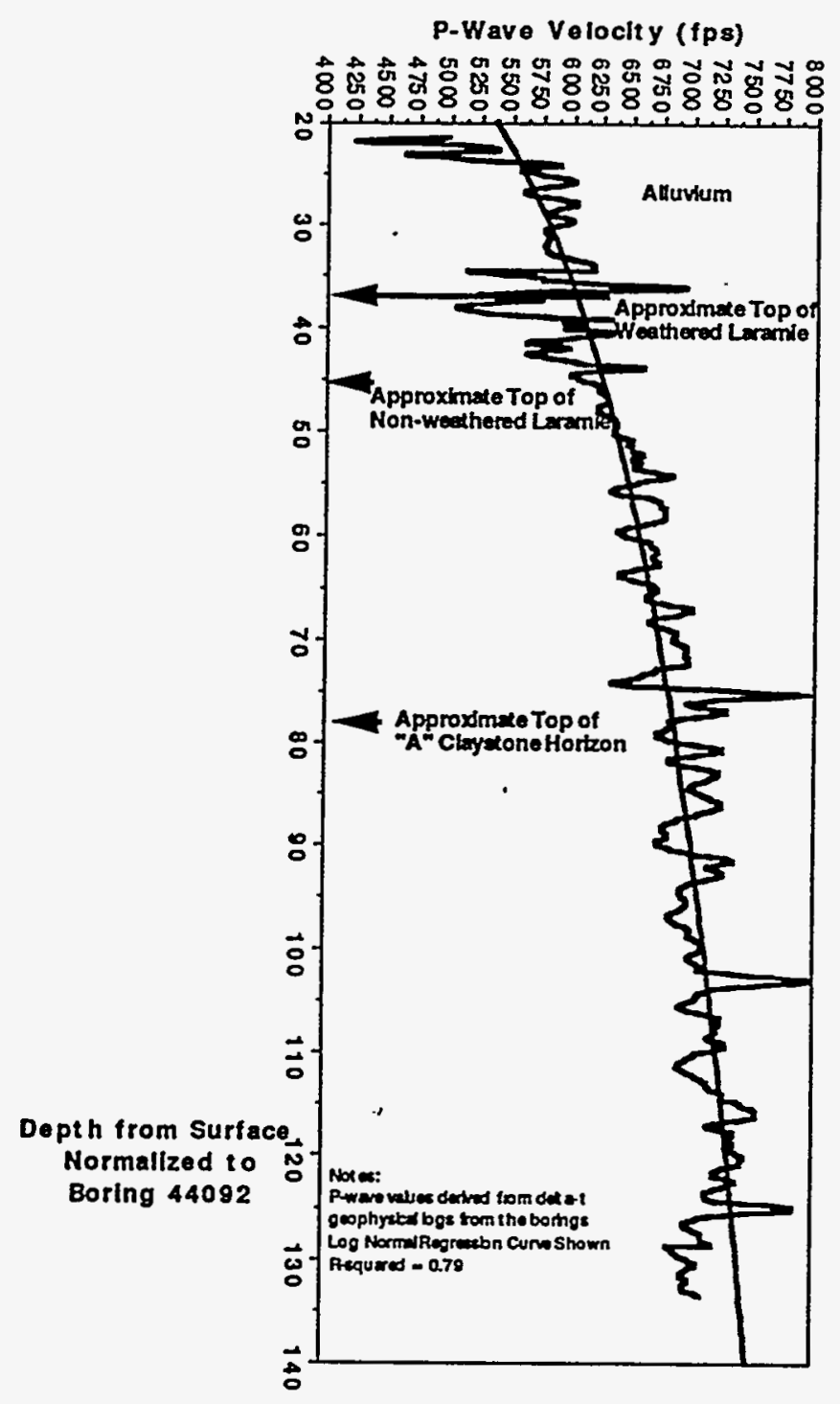

Figure 17

Averaged P-Wave Velocity Curve for Borings 44092, 43992, 44192 
WESTINGHOUSE SAVANNAH RIVER COMPANY E\&CS SITE GEOTECHNICAL SERVICES DEPARTMENT GEOLOGIC AND GEOTECHNICAL ASSESSMENT RFETS BUILDING 371, ROCKY FLATS, COLORADO
WSRC-TR-95-0482 REVISION 0

December 13, 1995

Page 41

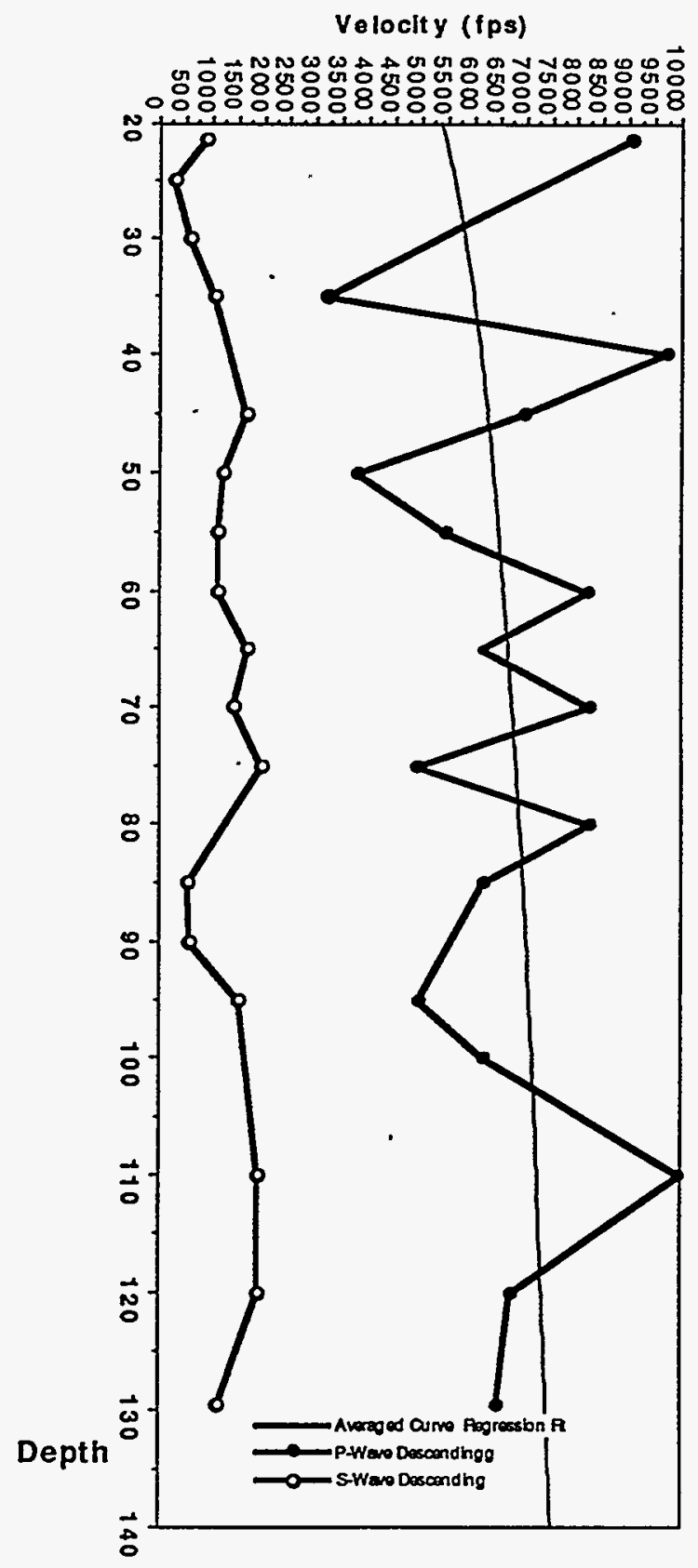

Figure 18

Blackhawk Hole-J Descending P- \& S-Wave Data Versus Averaged P-Wave Curve 
WESTINGHOUSE SAVANNAH RIVER COMPANY

E\&CS SITE GEOTECHNICAL SERVICES DEPARTMENT

GEOLOGIC AND GEOTECHNICAL ASSESSMENT

RFETS BUILDING 371, ROCKY FLATS, COLORADO
WSRC-TR-95-0482

REVISION 0

December 13, 1995

Page 42

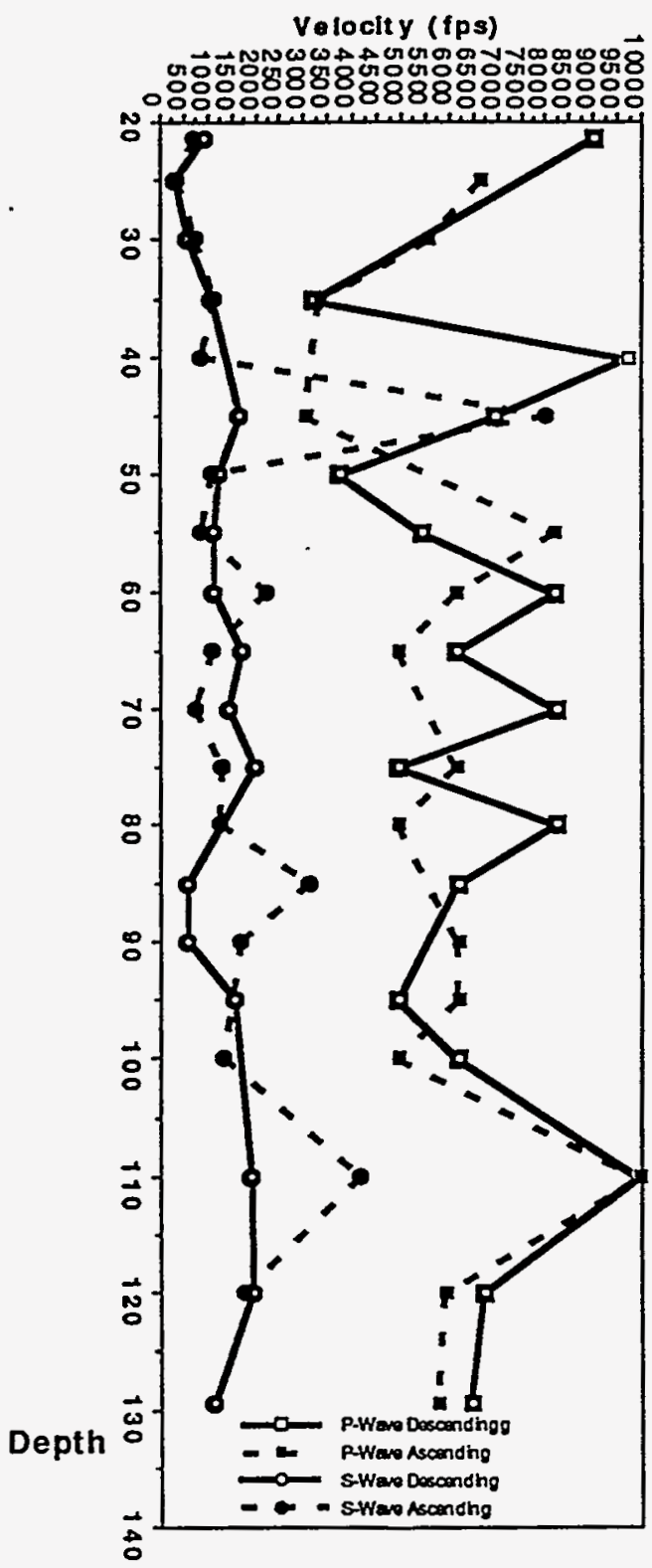

Figure 19

Blackhawk Hole-J Ascending and Descending P- \& S-Wave Data 


\begin{tabular}{lr}
\hline WESTINGHOUSE SAVANNAH RIVER COMPANY & WSRC-TR-95-0482 \\
E\&CS SITE GEOTECHNICAL SERVICES DEPARTMENT & REVISION 0 \\
GEOLOGIC AND GEOTECHNICAL ASSESSMENT & December 13, 1995 \\
RFETS BUILDING 371, ROCKY FLATS, COLORADO & Page 43
\end{tabular}

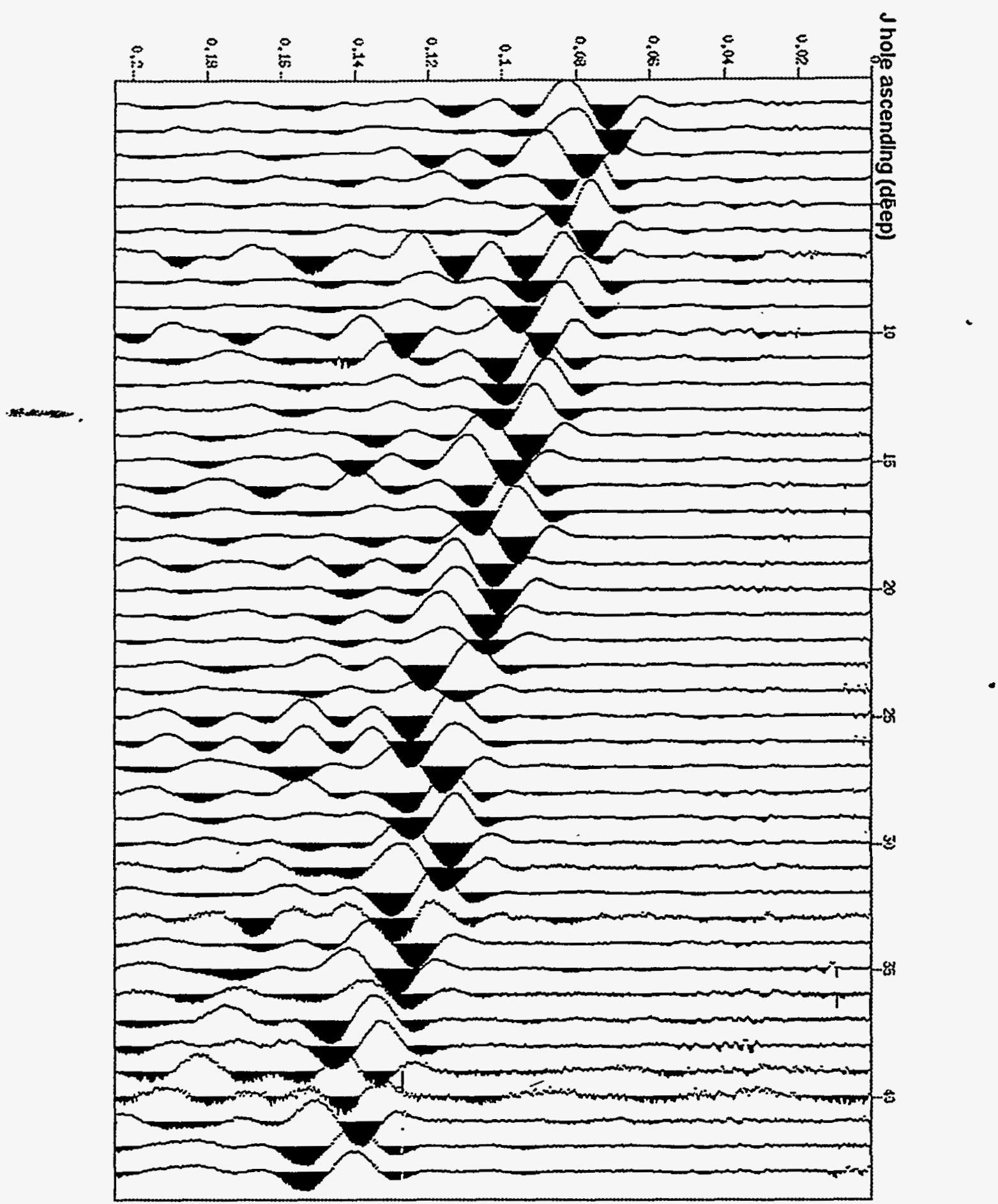

Figure 20

Hole-J “Ascending" Raw Recorded Motions vs Depth 